Portland State University

PDXScholar

6-1-1968

\title{
Intaglio printmaking in the secondary school
}

James Lester Wylder

Portland State University

Follow this and additional works at: https://pdxscholar.library.pdx.edu/open_access_etds Let us know how access to this document benefits you.

\section{Recommended Citation}

Wylder, James Lester, "Intaglio printmaking in the secondary school" (1968). Dissertations and Theses. Paper 562.

https://doi.org/10.15760/etd.562

This Thesis is brought to you for free and open access. It has been accepted for inclusion in Dissertations and Theses by an authorized administrator of PDXScholar. Please contact us if we can make this document more accessible: pdxscholar@pdx.edu. 
AN ABSTRACT OF THE THESIS OF

James Lester Wylder for the Master of Sclence in Teaching Degree in Art presented on May 19, 1968.

TITLE: Intagl10 Printmaking in the Secondary School ABSTRACT APPROVED:

James Hlbbard

There is a wealth of printed materlal on intaglio printmaking techniques and history, but there is relatively ilttle printed material or work directed towards the inclusion of intaglio printmaking in the secondary school art ourriculum. It is my basic assertion in this thesis that intagiio printmaking can be taught with success at the secondary level.

The thesis consists of three chapters. The f1rst chapter is conoerned with the purpose, value, and application of intagl10 printmaking in a secondary school art program. The second chapter identifies the materials, the cost of materlals, and the sources of supply. Chapter three deals with the orgenization of materials in the classroom.

Photographs of intaglio prints comprise the visual aspect of the thesis and supplement the text in some 1nstances. I have supplemented the photographs of my own work with orlginal prints by high school students, which should glve some 1dea of the student's competence. 
Photographs of some of the paintings and drawings that I completed during the Master of Sclence in Teaching program are in the appendix. This will provide a record of my work for the art department and is intended as a supplement to the thesis. 


\title{
Intagl10 Printmaking in the secondary school \\ by \\ James Lester Wylder
}

\author{
A THESTS \\ submit ted to \\ Portland State College
}

in partial fulfiliment of

the requirements for the

degree of

Master of Solence in Teaching

June 1968

PORTLAND STATE COLLEGE

LIBRARY 


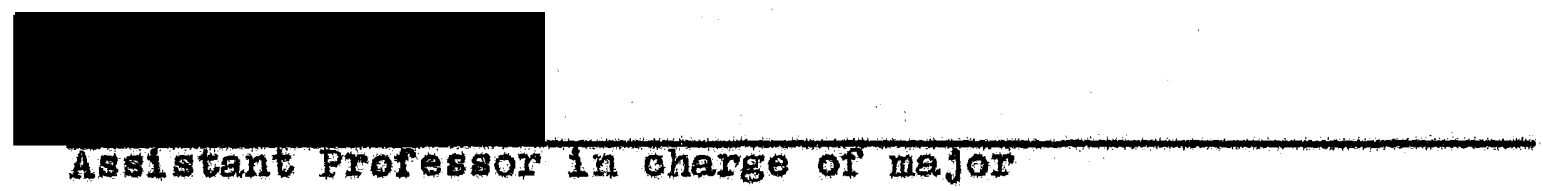

Assistant Professor in charge of major

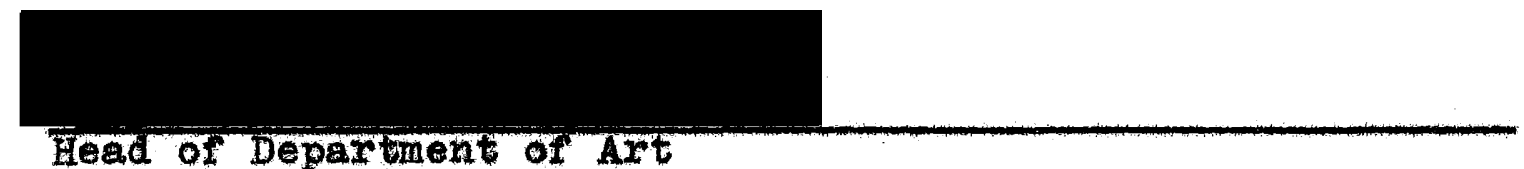

Head of Department of Art

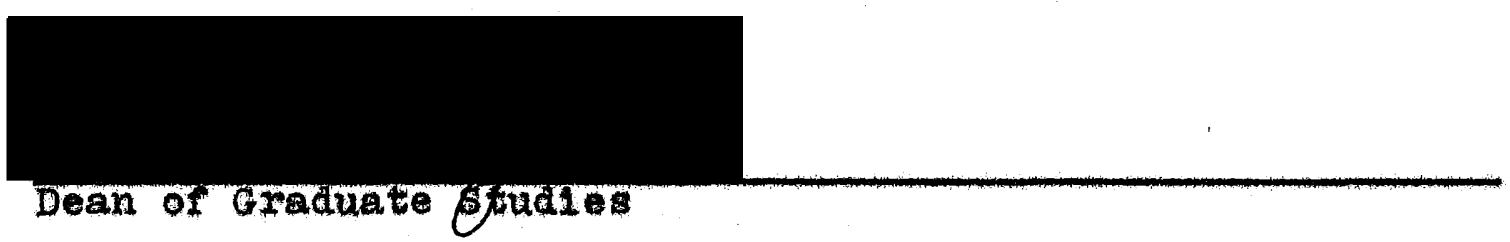

Date thesis is presented

May 2, 1968 
I. The Purpose, Value, and Application of Intaglio Printmaking in a Secondary School Art Program.......

II. The Materials Used in the Intagl10 Process..... 8

A. Materials that become permanent investments

of the art department................... 8

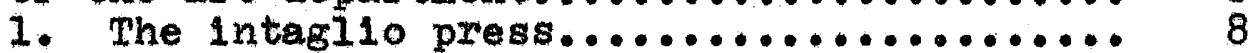

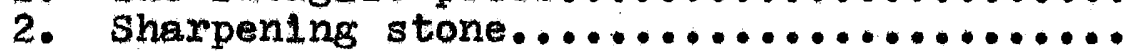

3. Gravers............................

4. Scraper............................

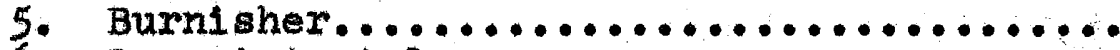

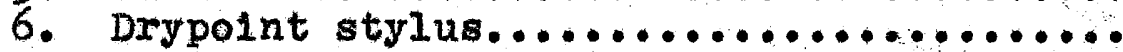

7. Wood and Ilnoleum block cutting tools....

8. Files.............................

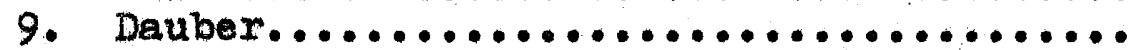

10. Brayer...........................

11. Glass plate .......................

12. Hot plate...........................

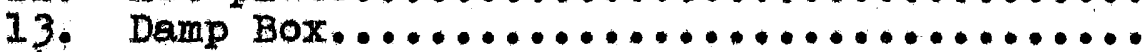

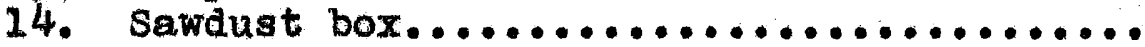

B. The materials that need to be replaced

pertodlcally..........................

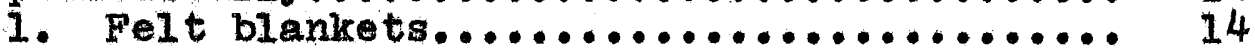

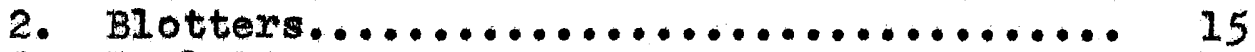

3. Tarlatans........................ 15

c. The materials that are consumed in the

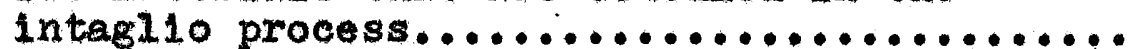

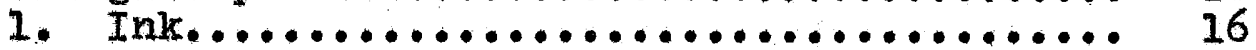

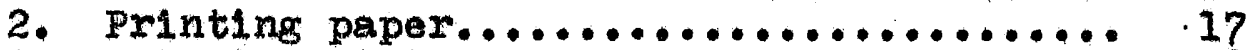

3. Printing plates..................... 18

4. Cleanlng solvents................... 21

5. Sandpapex........................ 22

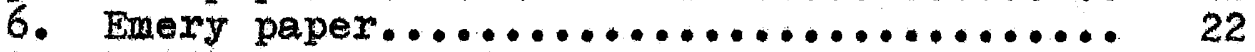

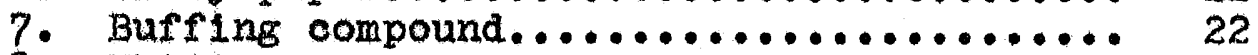

8. Whiting........................... 23

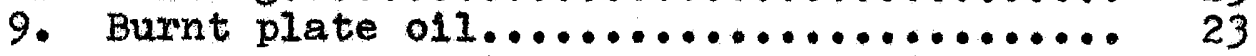

D. Cost of materials.................... 25

E. The sesential materials 11lustrated........ 27

F. supply compantes...................... 28 
III. The Organization of Materials in the Classroom... 30

A. The steps of the printing procedure in chronological ordex......................

B. The plates and the organization of the press

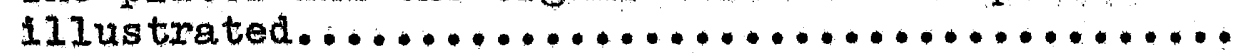

IV. Photographs of Thesis Prints............... 35

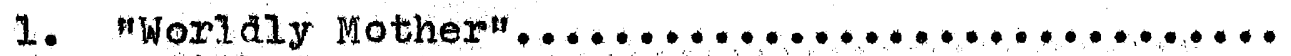

2. unt1tled............................

3. "Gloomy Sunday" .......................

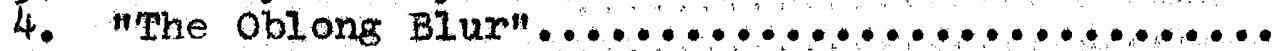

5. wravall" $\ldots \ldots \ldots \ldots \ldots \ldots \ldots \ldots \ldots \ldots \ldots \ldots \ldots \ldots \ldots \ldots \ldots \ldots$

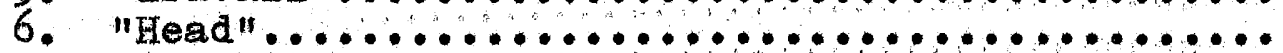

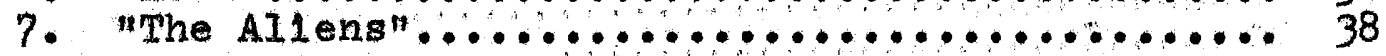

V. Prints by Students from Cleveland HLgh School..... 39

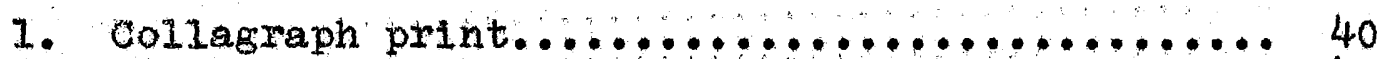

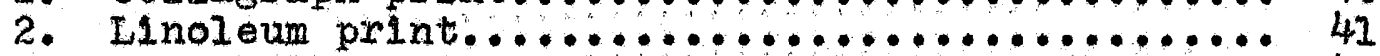

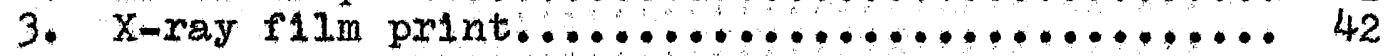

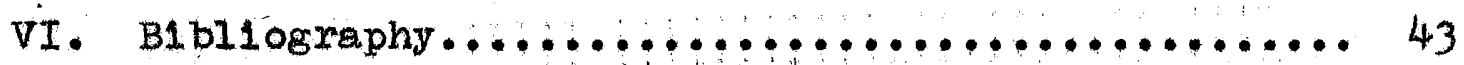

Append1x................................. 44

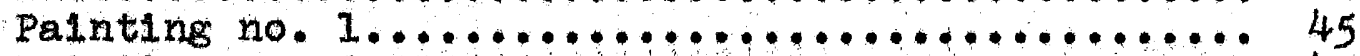

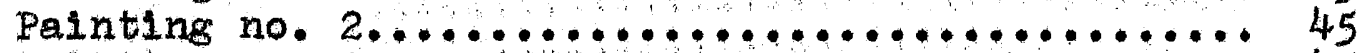

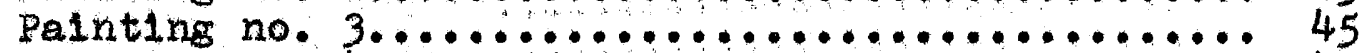

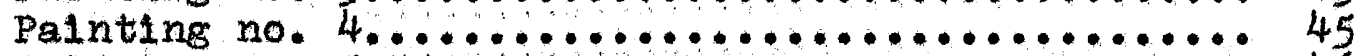

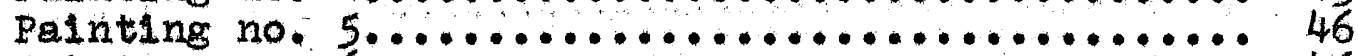

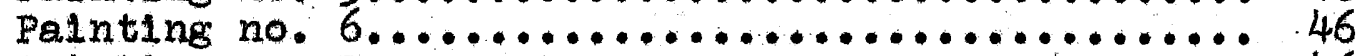

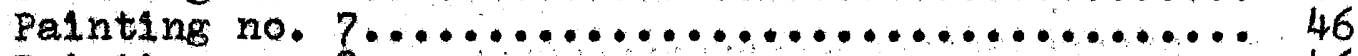

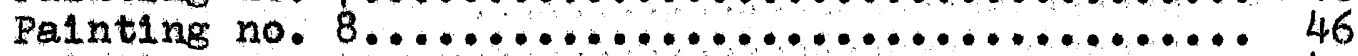

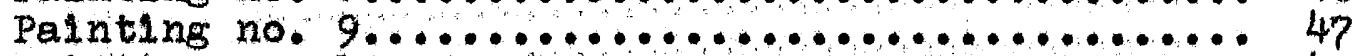

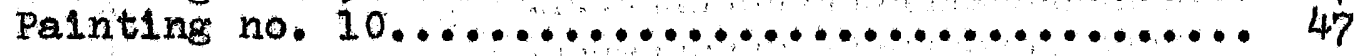

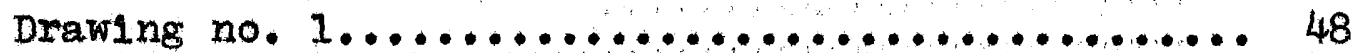

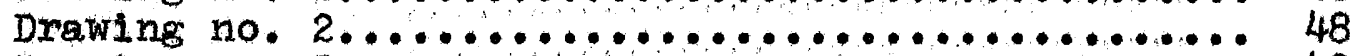

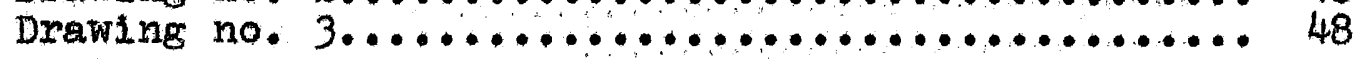


I. The Purpose, Value, and Application of Intagilo sxintmaking in a seoondary school Art exogram.

1. Purpose: The art classroom of the secondary school has been acqualnted with the rellef processes of wood blook and 1 inoleum and with silk sereen printing for a long time. With the exception of few scattered inctances, intagllo printing has been reserved for the collego art department. It 1 s my feeling that the intag110 process has learning possibilities for the secondary student beyond the rellef and screen processes. This thesis is conoerned wi th adjusting classic intaglio procedures and materials to the art olassroon of the secondary sohool. It is to be assumed that the reader 1 an art teacher with some experience wh Intagllo printmaking, perhaps one oollege olass devoted to this subject. The major adjustrent is the subst1tution in materlals used for the plate. Tlies, 11noleum. $x$-ray rlins, and other synthetic products are used in Ileu of metals $11 \mathrm{ke}$ oopper and zino.

My research has shown me that intagl10 is offered only in the Denver, some North Dakota, and Albany, New York public sohools. Intagilo printing deserves much more attention at the secondary level. This process w111 involve the student in an esthetic appreciation of the graphic axt that he may encounter in books, advertising. art museure, and art gallerles whlch are beginning to show 
prints more of ten.

2. Value: The ability to draw is the foundation for almost all art activities. The sketch can be a few Ilnes or it can be an elaborately developed study of 11 ght. shade, and form. In any case, the sketch is preliminary to work on the plate. A great deal of the teacher's time is spent teaching students to see and to draw what they see.

Sensitivity to Iine is augmented and extended by work in the intaglio media. One may think of a print as if it were a drawing that could be repeated. Once this 1dea of an exaotly repeatable image is fully understood by the student, he w111 be more selective in how and what he wants to draw. A soft. misty, or moody subject would be rendered most effectively by drypolnt ilnes which have a soft, fuzzy qual1ty. The action of working machinery or the intricacies of a complicated form can be rendered with clear. concise, engraved 11nes. The Intaglio process produces an embossed IIne that takes on the authority of the printed page. Subtle nuances of various intaglio media must be considered. The student should ask himself. "What will be the best medium to use for interpreting my theme?" This question is a good starting point for a class disoussion of materials and techniques of working. I like to give the students complete freedom to choose their theme. Th1s w111 assure some personal investment by the student in the project. 
The intaglio process works in slow motion. Each phase may be examined in detail. The preparation for the design furthers the student's knowledge of composition. The search for an appropriate 'syntax' of line and texture to render the design broadens the student's awareness of the variety of these elements. Engraving. gouglng, and soratohing the plate 1 s a manual and intelleotual exerclse that will enlarge the student's knowledge of materials and techniques. Inking and printing the plate is an aspect of the 1ntagl10 prooedure that w111 further the student's awareness of how printed material 11ke newspapers, books, and magazines are actually produced. The resulting edition of prints is a visual record of the student's efforts and may be compared and contrasted with professional prints to further the student's appreciation of intaglio as a medium for expressIon in the fine arts.

The modern intag110 printmaker has a long and interesting herltage on which to base his art. William Ivinst book Prints and Visual Communication is an excellent reference to this heritage. He traces the history of printmakins In an effort to "find a pattern of significance in the story of prints." I He approaches the subject from a soclological point of view indioating cultural effects on

1 W111 lam M. Ivins, Prints and V1sual Communication (Boston, 1953). p. 8 . 
prints, their shifting significance during various periods of history, and the mechanical evolution of technique. This book is fundamental for the understanding of the history behind modern printmaking in all media.

3. Application: The secret of teaching intaglio seems to consist of a minimum of explanation on the part of the teacher and a maximum of experimentation and discovery on the part of the student. students of ten discover ways of working that the teacher has completely overlooked.

Four atudents from Cleveland High Sohool, Portland, Oregon were selected to partiolpate in a workshop on 1ntaglio. The alms of the workshop were:

A. to prepare these students for fliming a video tape on Intaglio scheduled for the following week

B. to elarify teaching methods in presenting intagl10 on the secondary level

C. to note the time that the students required to complete an intagl1o print

One hour each afternoon for flve days was devoted to this project.

Three girls and one boy were selected. The girls were chosen because they might have more diffloulty with the technical aspeots of intaglio and therefore help clarify information that would be needed to present the process to a class. One glrl worked with an $\mathrm{x}$-ray plate, one with a Iinoleum block, and one with a collagraph plate. The boy 
produced a wood ongravine and a drypolnt roo an $x-x a y$ plate. Twenty minutes of the first day was devoted to expialnIng the intagilo process to the students. In the lest porty mutes the students were enoouraged to experiment w1 th the tool and weterials and to ask questions. The rest of the weak was devoted to working with the students Individually. Sach student drew soverni designs and ueleoted the design that wal most aulted for the mediun that he had chosen.

It 1s agential in intagilo that the plate is textured In sowe manner so that the plate w111 hold the 1nk. The atudents were not adept at bullding up passages of dark tone wh 11 nes; they wanted to gouge out the entiro area of the plate that would be ark. However, there was never a question about hich area of the plate printed nor that the print would be the reverse of the plate. Baoh student devoloped his own working methods with the tools and competed to oreate unique textures and unusual effects. The materlals were pushed conslderably beyond thelx expected IInat ts.

The x-xay flin and Inoloum plate that the students had experinented wh on the first day wero printed the second day with a craftool press. The rosultung prints were very userul examplen of the possiblitties of the wedla. vach student wa able to see how hl a scribble had printed. The print were passed around for examination 
and motated on a bulletin board for reference. The wiplin of the plate and the printing procedure were also demonstreted duxing this meond session.

By the end of the weex each student had produced a plate and one print, the format of the video tape was d1 scussed and the tudents reviewel thelx parta.

During the forty-ninute taping session each student cemonstrated the ure of the tools and howed examples of his prints. I Introduced the filn with brief disoussion of the prooess and 1 ed a ceminar at the end. An attempt wa mede to aray out reactions to the prooess and to the Images they had produced. Myploal student ooments in tha regard rolkow

"I wasnt conoerned ith deslgn. I wanted to use the tools and find out what they would do. The $x$-ray fllm responds to tools immediately and I vould $11 \mathrm{ke}$ to try amething that takes Ionger. I think that you control the lmage by the material you use,"

"The quietness I wanted to express is not thexe. The print 1. too dark and heavy. PIywood absorbs a lot of 1 nik and I think that next time I would stay with 11noleun "

"I used netting, atring, tape, araboard, and glue on the collagraph. This gives dark, rioh texture to the print that I 11ke, I also Ilked the embossed print that we did whout inklng the plate,"

"Next time I 111 make more arawing before $I$ etart on the plato. The rood onstaving did not turn out because the Ilnes rexe too alose together. There 1 no signtelonce for in other people's art. I nuterstand my own art I 11ke it but I don't know why. I notlee texture and I like the eraboseed print but 1 toesn t man anything to me 
unless I do it myself."

"I enjoy working with other media like clay but I don't have any faclilties and there is not enough time at school. I think that design carries through from one medium to another and it almost dictates what you present--mood, form."

The most frequently mentioned oriticism was that more drawings should have been done before working on the plate. The students agreed, however, that it was difficult to do a good job with intaglio the first time and expressed a willingness to investigate intaglio further. They liked the idea of printing from Ines below the surface of the plate. This was their flrst experience with intaglio media of any kind.

In summary, it is proposed that intag110 can be adjusted to meet the needs of the art classroom of the secondary school and that intaglio is a significant aspect of a total art curriculum. 
II. The Teterials Used in the Intagl10 Process, Their Cost and the Sources of Supply.

There are three categories of materials that the high school teacher should be concerned about: 1. the materlals that never need replacing and require only periodic malntenance, 2 . the materlals that need to be cheoked or replaced every few months, 3. the materlals that are used up during the school year and must be restocked. I have provided a list of these materials with the quantity that should be ordered to supply a class of thirty students, drawings of important tools and equipment. and a list of supply houses.

A. Materlals that become permanent investments of the art department

1. The Intag110 Press

One of the major considerations of the secondary school is that of price. The Sturges model Graphic Chemical presses, the Brand etohing presses, the Rembrand etching presses, and the Craftool etohing presses meet the requirements of the professional printmaker. Craftool, Inc, has produced a press (art press no. 4112) for 149.50 that is popular in the secondary schools. It has been on the market for a number of years and has proven to be an adequate and versatile piece of equipment. The high price of a professional press is prohlbitive 
for most school budgets. Therefore, the craftool model (no. 4112) is recomended. For more detalied information on intaglio presses, refer to Hayter's comments in his book, New ways of Gravure and About Prints.

The printing press will be the largest single investment and ranges in price from the $\$ 249.50$ Craftool model to several thousand doliars for a huge electric powered precision press. It is often possible to cut the price of the press considerably if an old weshing machine wringer or a steel mangel can be found in a looal thrift shop. 2

\section{Sharpening Stone}

The best stone is the 'Behr-Manning hard Arkansas grooved stone, sold by Frank M1termeler. Inc. for 9.35 . The stone has four grooves that are machined to $1 \mathrm{~mm}, 2 \mathrm{~mm}$, $4 \mathrm{~mm}$, and $8 \mathrm{~mm}$ on one slde, and 1t is flat on the other side. Th1s stone is 1deal for honing gouges and gratrers. The cost is not prohibitive (about $\$ 2.00$ more than the cost of a stone flat on both sides) because this stone saves the student and the teacher time and gives the best possible cutting edge to the tools. Pontana Assay does not advertise the grooved stone but their prices on other stones are $\$ 20$ to $\$ 30$ less than Mittermeler.

2 See Ernest $\mathrm{s}$. Lumsden. The Art of Etching (Iondon. 1925) p. 19. 
Plke o1l is used on the stone while the tools are belng sharpened. It is $\$ 1.00$ per pint and will last for whs school year since only a small amount is used each time.

\section{Gravers}

Gravers are used for engraving. There are flve basic styles of gravers shown on page 27. Two of each kind should be purohased by the art department. This means that ten students can engrave while the others are using the drypoint or etching tools. By rotating the three processes, thirty students w111 have a chance to become familiar with each. The Montana Assay office, Frank Mittermeler, Inc., and the Graphlo Chemloal and Ink Co. are major suppliexs of these tools. The tools are offered individueliy and in sets. It is less expensive when the gravers are bought individually and mounted into 'half-head, short' handles. The handles are $\$ 1.75$ per dozen and the metal shafts are $\$ .60$ each (Montana Assay price). Graphlc Chemical and Ink Co. sells gravers with a bent shaft as shown on page 27. A tool with a bent shaft is preferred for ease of handing.

4. Soraper

The soraper is used to scrape the burr from the engraved plate and to resurface areas of the plate when corrections are needed. It has three faces that come to a point. The edges should be kept very sharp. Each table 
of students should have access to a scraper. Montana Assay's price is 1.20 each. Graphic Chemical and Ink Co.'s price is 1.85 each. There is no apparent difference in quality or style between Montana Assay's and Graphic Chemical and Ink's scraper.

\section{Burnisher}

Montana Assay lists a burnisher (no. 15-011竞)

with a curved blade for 1.15 . The burnisher was origlnally a jeweler's and goldsmith's tool as were the burin, scraper, and drypoint stylus. For intagilo printing, burnishers are used to finlsh polishing the edges of plates and for pressing down and polishing areas in the plate's surface.

6. Drypoint stylus

Ten drypoint tools should be purchased by the art department. Montana Assay's 'Wallersor1ber' (no. 21-457) with a solld carbide tip is $\$ 1.25$ and will hold up well under constant use. The steel styluses 11 sted are ${ }^{\circ} 10$ to \% 15 cheaper but w111 not wear as well.

7. Wood and Iinoleum Block Cutting Tools Frank Mittermeler. Inc. advertises a large variety of these tools. ranging in price from $\$ 1.20$ to several dollars per tool. These tools are dellcate and the cutting surface is eas11y injured. Several Japanese companies have marketed a set of six to ten tools that range in price from $\$ 59$ to 1.00 per set. The Japanese sets are 
preferred at the secondary level because they are sturdily constructed and because they are inexpensive. Most art departments will already have a set of the Japanese tools, the familiar speedball tools, or the more expensive Milier Falls tools.

X-acto knives or pen knives are commonly stocked also and are needed for wood and linoleum blocks. They cost .60 each.

8. Flies

Three flat metal files are needed for beveling the metal plates. The fine, medium, and coarse grades should be purchased in $6 "$ or $8 "$ lengths. The cost per file ranges from 1.15 to $\$ 2.25$. Montana Assay supplies these files and thelr median price is $\$ 1.40$ per file.

\section{Dauber}

The dauber is used to spread the ink on the printing plate. Graphio Chemical and Ink Co. advertises a rolled relt or leather dauber for $\$ 2.90$. This price seems unreasonable since a daber can be made in less than flve minutes by rolling an old leather belt, outting a $2^{\prime \prime}$ by $3^{\prime \prime}$ plece of cardboard, or rolling a plece of felt from a worn blanket. If felt or leather is used, the

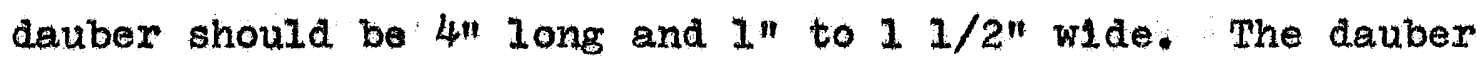
is used for inking engraved and etohed plates because 1 will force the ink into the engraved 11nes. 


\section{Brayer}

A rubber brayer, four inches long, is sometimes preferred for 'rolling up' the plate. A brayer is used to Ink the drypolnt plates because a dauber will injure the Iarypoint burr'.

11. Glass Plate

A thlok plece of glass at least 12" square should be purchased and gently ground with 220 carborundum. The sand-11ke carbomundum textures the glass plate. The Ink w1Il not slide or run on this textured surface.

12. Hotpiate

Expens1ve hotplates are offered in the supply catalogues for professional printmakers. Students, however, get along very well with the cheapest hotplate avellable. If there is a gas burner in the art room, a metal plate (w1 th steel legs) can be positioned half an inch above the burner like a griddle. The hotplate is used to warm metal printing plates while inking and before printing. The hotplate w111 probably never be used above the 'Iow' setting.

\section{Damp Box}

A wooden box 12" deep, 20" w1de, and 25" Iong should be made to hold the blotters. The box must elther be Iined with plastic or heavily varnished to protect it from the damp paper and blotters. 


\section{Sawdust Box}

A box. 8" deep and 18" square or larger, should be made to hold sawdust, The sawdust is soaked with kerosene and is used for cleaning hands.

B. The materials that need to be replaced periodically

\section{Felt Blankets}

The felt blankets take a lot of abuse and are used by every student each time he prints. The press flattens the blankets and they begin to lose the spongy quality that is necessary to force the papex into the printing plate. The Continental Felt Co. is the major supplier of felt and they list flve grades by width, weight, and thlokness. Three felts are needed for olassroom use, The width and length of the felts is determined by the size of the plate and also by the s1ze of the press bed. Student work is generally smaller than 21" $x 27 "$.

The bottom blanket is called the slzing oatcher and is 1/16" thlok (style no. 6028). The middle blanket is called the cushion and 1 s $1 / 8^{n}$ thlok (style no. 6054). The thlrd blanket, called the pusher, can be 1/4" (style no. 1547) or $1 / 8$ " thiok.

Continental Feltrs basic price is $\$ 5.00$ per pound and the blankets can be out to the desired size for a slight extra charge or it can be easily done by the purchaser. The 1/8" blanket (no. 6054) out to $21 " \times 27$ " would cost 
less than $\$ 6.00$. The cost of all three blankets this size will be around $\$ 20.00$. Shlpment can be made from Continental Felt in approximately one week. Graphic Chemical and Ink Co. IIsts blankets at slightly higher prices and they are less specific about the weights and textures.

The blankets should be $100 \%$ wool and they must be treated with the utmost care. "Blankets should be washed in soap and warm water at the slightest tendency to harden. Blanket rlgidity, caused by absorption of the size in printing paper, is often the cause for poor printing." 3

\section{Blotters}

Twenty-four blotters (one quire) should be purchased from Graphic Chemical for 2.50 . They are 19" $\times 24 "$ and will be stacked and welghted with a flat, heavy plate In the 'damp box'. They should be neat, clean, and always ready to recelve the wet etching paper between theix pages. The blotters will last for a long time if they are carefully handled with a clean cardboard clamp.

\section{Tarlatans}

Tarlatans are starohed cheesecloth and are used to wipe the plate. They are avallable from Graphlo Chemlcal at \$.35 per yard with a 36" width. Mr. Joseph Sernberg,

3 Jules Heller. Printmaking Today (New York, 1958), p. 136 . 
Newark Dressmaker Supply Co.. sells tarlatan at $\$ .35$ per yard In a 54 " widh but only in 240 or 120 yard 1ots. It would be more expensive to buy from sernberg. However. 120 yards w11 last for a long time and the 54" widh is preferable. Flfteen yards of the 36" with should supply a classroom for one year or longer.

c. The materials that are consumed in the intaglio prooess

\section{Ink}

Intagl10 printing ink is a mlxture of burnt plate 011 and pigment. The mixtures of plgment and oil vary accordIng to the size of the pigment partiole.

Etohlng ink is the most sultable ink for intaglio and can be obtained from nationally known art supply fims. It is a stiff. oll base, black lnk that drles slowly (about three days after printed to allow the artist plenty of time to work with it on the plate. Etohing vine black ink (no. 1014) is sold by Graphio Chemical and Ink co. in a pound can for \$3.00. This ink can be used with success on al1 plates that cannot be neated. It can be mixed with a small amount of plate o1l to make wiping the plate easier. There are a number of other black Inks avallable at a lesser price, but the vine black seems to be the most popular and has the most oonsistent qual1ty. Colored and black Inks can be purchased as dry plgments and mixed. This w111 reduce the cost conslderably. Refer to Jules Heller's 
Printmaking Today, David strang's The Printing of Etchings and Engravings, and E. S. Lumsden's The Art of Etching for ingredients and methods of mixing intaglio ink.

\section{Printing Paper}

Newsprint or inexpensive drawing paper can be used to 'proof the plate at various stages of development. A quality etching paper should be used for the final edition of prints.

The paper must be strong enough to mold to the plate without tearing when it is damp. The paper is usualiy graded by the manufacturer by weight, tensile strength. sizing, opacity. printability. and other factors. 4 There are many k1nds of papers that are sultable for intag110 printing from very thin rice paper to heavy fatercolor paper. Some art stores carry paper especlally designed for intaglio printing. The main criteria is 'wet strength' that 1s, the paper must be strong enough to mold to the plate without tearing when it is damp.

Andrews. Nelson, and Whitehead have several papers that are suitable for intag110 printing. The Copperplate papex. 30" $\times 421 / 2 "$ size. 1a $\$ 60.00$ per hundred for any quantity between 100 and 249 sheets. The Domests.c etohing paper. $26 " x$ 40" size, is $\$ 28,00$ per hundred for any quantity between 100 and 249 sheets. The Rives paper,

4

See Zellerbach Paper Company's booklet, The Testing of Printing Paper. 
White and buff 11ght 19" x 26" s1ze, is \$20.00 per hundred for any quantity between 100 and 249 sheets.

In order to estimate correctly the amount of paper that a class of thirty students will need, the following points should be kept in mind:

a. The paper is out 2 inches larger than the plate

b. There w111 probably be less than three print editions completed during the semester by each student c. There will be mistakes and corrections that w111 require additional paper

Inexpensive rice paper, which is six to elght dollars for 500 sheots, can be backed with a plece of construction paper to help hold that paper together. The rice paper provides the quality surface and the construction paper provides the strength.

3. Frinting plates

a. Copper

Red copper for engraving and etching is avallable from Graphic Chemloal and Ink Co. for \$.06 per square inch. National steel and Copper co. has a 16 gauge, 24" x 36", copper sheet that sells for $\$ 30.00$ per sheet. Other suppliers are the Harold P1tman Co. and Rembrandt Graphic Arts Co. Copper should be bought in as large a sheet as possible and cut to size with a hacksaw or saber saw for classroom use. The cost of copper is almost prohibltive and should be reserved for advanced students, unless the 
students buy $1 \mathrm{t}$ themselves, It must be kept in mind that the price of copper is fluctuating very rapidiy at this time.

b. Zinc

Zino is avallable from Graphic Chemical and Ink co. for 03 per square inoh end from Copper and Brass Sales, Inc. Zinc is eas1.y worked and is more sultable for secondary school use than oopper.

\section{c. Aluminum}

Rembrand Graphic Arts selis uncoated aluminum plates in $6 \times 8,8 \times 10$, and $9 \times 12$ inoh s1zes for $\$ .55$. 65 . and $\$ 1.90$ respectively. They also sell an etching powder for aluminum (no, 3015) that is dissolved in water and harmless to the skin. These plates are 11ght, easy to work, and sultable for engraving, drypoint, and etching.

d. Plastic

Rembrand Graphic Arts sells a set of twelve 20 gauge plastle plates in several s1zes. The $9 \times 12$ inch plates are \$4.00. These plates could be cut in halves or quarters to serve an entire class.

\section{e. Iinoleum}

Squares and sorap pleces of 11 noleum can be obtalned from looel floor covering fims. These flrms w11l often give the scraps away if they know that it is intended for school use. There are so many kinds of Ilnoleum that it is Impossible to describe all the printing characteristics. 


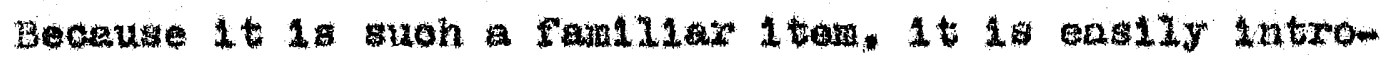
duced into the olassroom and the atudenta foel at esse working with 1 .

\section{f. Plywood}

Finlshed plywood is avaliable in $41 \times 8$, she ta for about 3.85 from local lumber oompang. The 1/4n thlok plyood $1 \mathrm{a}$ best. It oan be arved wh the wood outting tool ox the pen kntre and w11 show 1 ta graln on the print. one board w11 aupply an entire class.

\section{c. Wazont to}

Tetrered masont to 13 also avallable in 4 ' $x$, sheats from Iumber ooxpanio for about the same price as plyood. Burins, penknives, and roodoutters on also be used. Masonite is one of the most versatile of all printing aurfacea,

$$
\text { h. } x-x+y=11 m s
$$

These flims are free from any x-ray department or hospltal. Thay axe aultable for arypolnt, they print we11; and they are easily wored.

\section{Expeximental Plates}

I ware that there are many other matex'als that would make aul table printing plate. The collagraph' method, developed by Glen Alps the universtty or Washington, seattle. Waanington, of gluing bita of textural naterials, papere, sandpaper, and sand onto a mont te plate 1. worth tryirg. White glue should be used. Whe plate can 
be wiped and printed I1ke any other plate. Care should be taken that the materials are not in high rellef. If the plate were too thick. it might injure the blankets or the press.

4. cleaning solvents

a. Kerosene

Kerosene, commonly known as stove oll, is the most widely used solvent and can be purchased from a gas station for about $\$ 35$ per gallon. The students can use kerosene on their hands without harm. It is also less flammable than gesoline.

b. Aloohol

Denatured alcohol is used to clean the plates before grounding them for etching and before inking because it w111 not leave a residue or greasy flim on the plate. Denatured aloohol is \$.75 per pint.

c. Turpentine

Turpentine is used 11ke kerosene but it is more flammable and more expensive. Turpentine is 2.00 per gallon.

d. Hand Cream

Hand oream is used before handling ink to make cleanup easiex, especially for the girls.

e. Hand Cleaner

There are many commercial hand cleaners avallable for printers and auto mechanios. They can be found in auto supply stores in one pound cans for about W. $_{1}$. G. Graphic 
Chemical and Ink Co. has 'Perfection Hand Cleaner' for $\$ .60$ per p1nt.

f. Asphal tum Thlnner

Turpentine may be used to thin asphaltum ground if it begins to thicken in its container.

\section{Sandpaper}

Most art departments have several grades of sandpaper on hand. It is useful for beveling the softer plates 11ke Iinoleum and plywood. I have also used sandpaper to roughen the surface of plates to oreate a tonal effect.

\section{Emery Paper}

Buy the finest grade emery paper (no. 0000) avallable to polish and remove scratches from plates and tools. About ten sheets of emery paper at $\$ 20$ per sheet from Graphic Chemical and. Ink co. should be cut into small squares for student use. The paper does not wear out as eas11y as sandpaper.

\section{Buffing Compound}

Red, standard jeweler's rouge (no, 52=450) comes in $1 / 8$ pound st1cks at $\$ 25$ per stick from Montana Assay. Three stlcks should be purchased. This can be used as a final polish for the plate before printing. The rouge should be applied in a ciroular motion with a pad of felt, a rolled felt dauber, or a cotton towel. There are many powders and rouges avallable. E. S. Lumsden's the Art of Etching has a brief passage devoted to this subject. 
8. Whiting

Whiting is a powder that is used to remove oll from the hands. It enables the printer to hand-wipe a plate with the palm or finger without 'drag' or smudging. The printer should wipe his hands on a rag to remove completely excess whiting before handling the plate. Graphic Chemtcal and Ink Co, sells whiting for $\$ 40$ per pound. Some paint and hardware stores sell whiting for as low as 巾. $^{2} 15$ per pound, or $\$$. 05 per pound in a bulk rate.

9. Burnt Plate 011

This oil is used as an aditive to the intaglio ink. One should mix a small amount of plate oll with heavy ink. especialily when the plate must be wiped cold. The heavy grade plate oll (no. 3) is the most suitable and is avallable from Graphle Chemical and Ink Co. for \$2,00 per quart.

Many materials have been excluded from this chapter. Howerex, I belleve that the present 11 st will be adequate in most instances. My research has shown that each book on intaglio reflects the author's bias for materials and technlques. Lumsden mentions almost all materials and techniques and gives his opinion of each. His book The Art of Etching is the recommended supplement for this chapter. Brunner's A Handbook of Graphic Reproduction. Heller's Printmaking Today. and Strang's The Printing of Etchings and Engravings are also good reference books. 
The various supply compenles respond to requests for catalogues within three weeks. For a prompt response, write a form letter on school letterhead paper. The amount of time required for delivery of an order varles for each company. A request for this dellvery information should be included in the letter for a catalogue.

Current price changes must be compared, especially when ordering metal plates. A price change list is included with catalogues that have been published more than one year back. The price ohanges should be written into the catalogue for easy reference. 
The Cost of Materials

PERMANENT MATERIALS

1. Press - Craftool

2. Sharpening stone

3. Burins

4. Burin handles - per doz.

5. 3oraper

6. Burnisher

7. Drypoint stylus

8. Wood and Iino outters

9. Pen knife

10. Files

11. Deuber - home made

12. Brayer - home made

13. Glass plate

14. Hot plate

15. Damp box - home made

16. Sawdust box - home made

$\begin{array}{rl}\cos T & \text { No. } \\ 149.50 & 1 \\ 9.35 & 1 \\ .60 & 10 \\ 1.75 & 1 \\ 1.20 & 4 \\ 1.15 & 2 \\ 1.25 & 10 \\ 1.00 & 5 \text { sets } \\ 1.60 & 5 \\ 1.40 & 3\end{array}$

2.00

10.00
TOTAL COST

149.50

9.35

6.00

1.75

4.80

3.30

12.50

5.00

3. 00

4.20

2.00

10.00

MATERIALS REPLACED

1. Felt blankets - per pound

2. Blotters

3. Tarlatans

5.00

2.50

.35

quire

20.00

2.50

5.25

MATERIALS CONSUMED

1. Ink

A. Vine black

B. Dry pigment - vine

3.00

$.65 \quad 5 \mathrm{Ib}$

6.00

2. Printing paper.

A. Domestio etching

28.00

B. Rives

20.00

100

3.25

C. Copperplate

D. Rlce paper

60.00

100

28.00

20.00

60.00

$6.00 \quad 500$

6.00

3. Printing plates

A. Copper $-24 \times 36 \mathrm{in}$.

$22 \cdot 32$

1

$22 \cdot 32$

B. Zinc - per sq. in.

.03

.55

10

5.50

D. Plastic $9 \times 12$ in. -

4.00

1

4.00

E. Linoleum - free

F. Plywood - $4 \times 8 \mathrm{ft}$.

G. Masonite $-4 \times 8 \mathrm{ft}$.

3.85

1

3.85

H. X-ray film - free

I. Experimental

4. Cleaning Solvents

A. Kerosene - BaI.

B. Alcohol - qt.

C. Turpentine - qt.

.35

.75

3
1
1

1.05

.75

.75 
materials continued

COST No. TOTAL COST

D. Hand Cream - price varies

E. Hand cleaner - pt.

5. Sandpaper - sheet

6. Emery paper - sheet

7. Buffing compound - stick

8. Whiting powder - pound

9. Burnt plate oil -qt.

$\begin{array}{rr}.60 & 2 \\ .20 & 10 \\ .20 & 10 \\ 1.25 & 3 \\ .40 & 1 \\ 2.00 & 2\end{array}$

1.20

2.00

2.00

.75

.40

4.00 


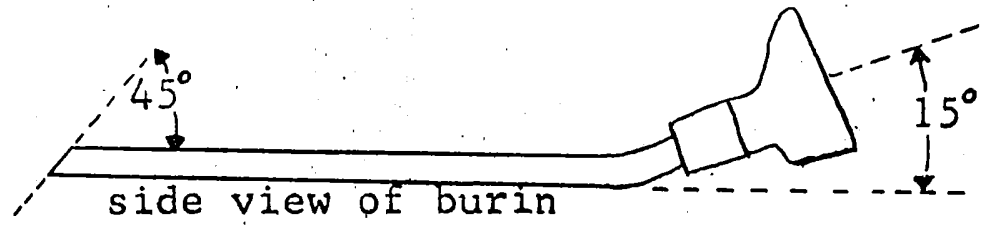

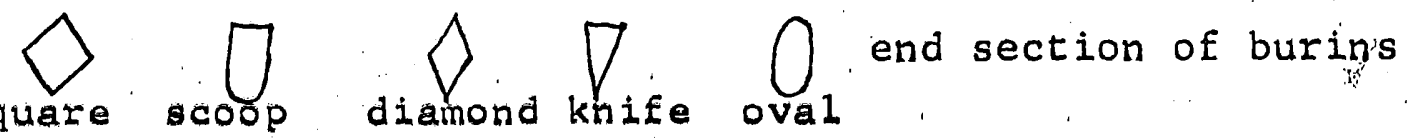
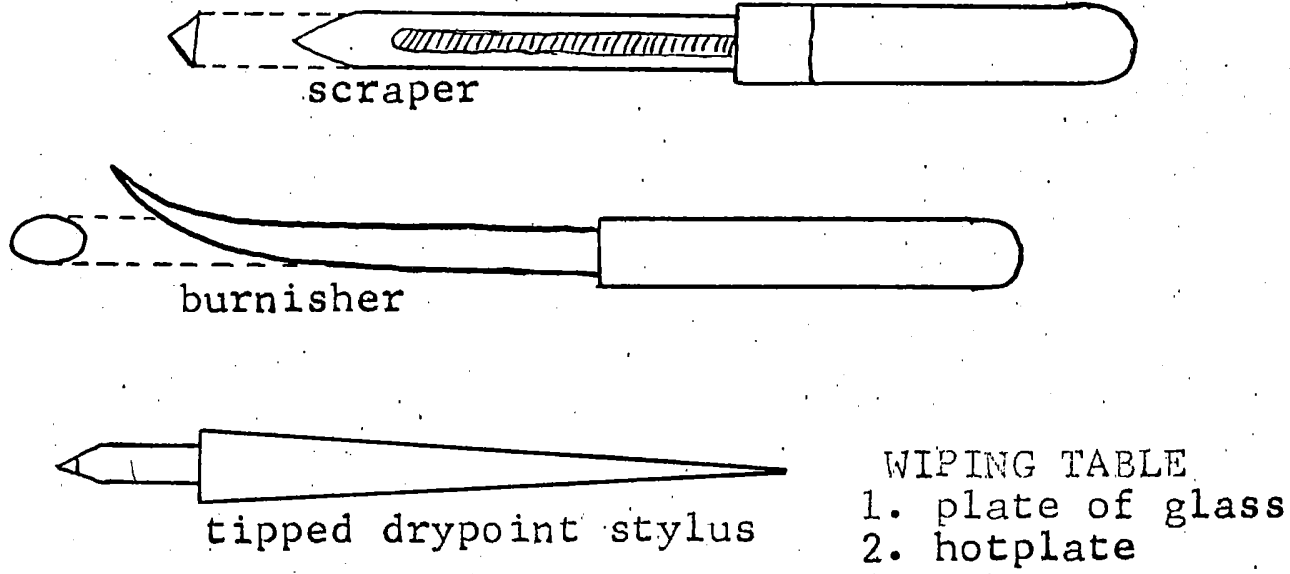

3. ink can

4. utinsel rack

home made drypoint stylus

5. brayer

6. spatula

7. newspapers
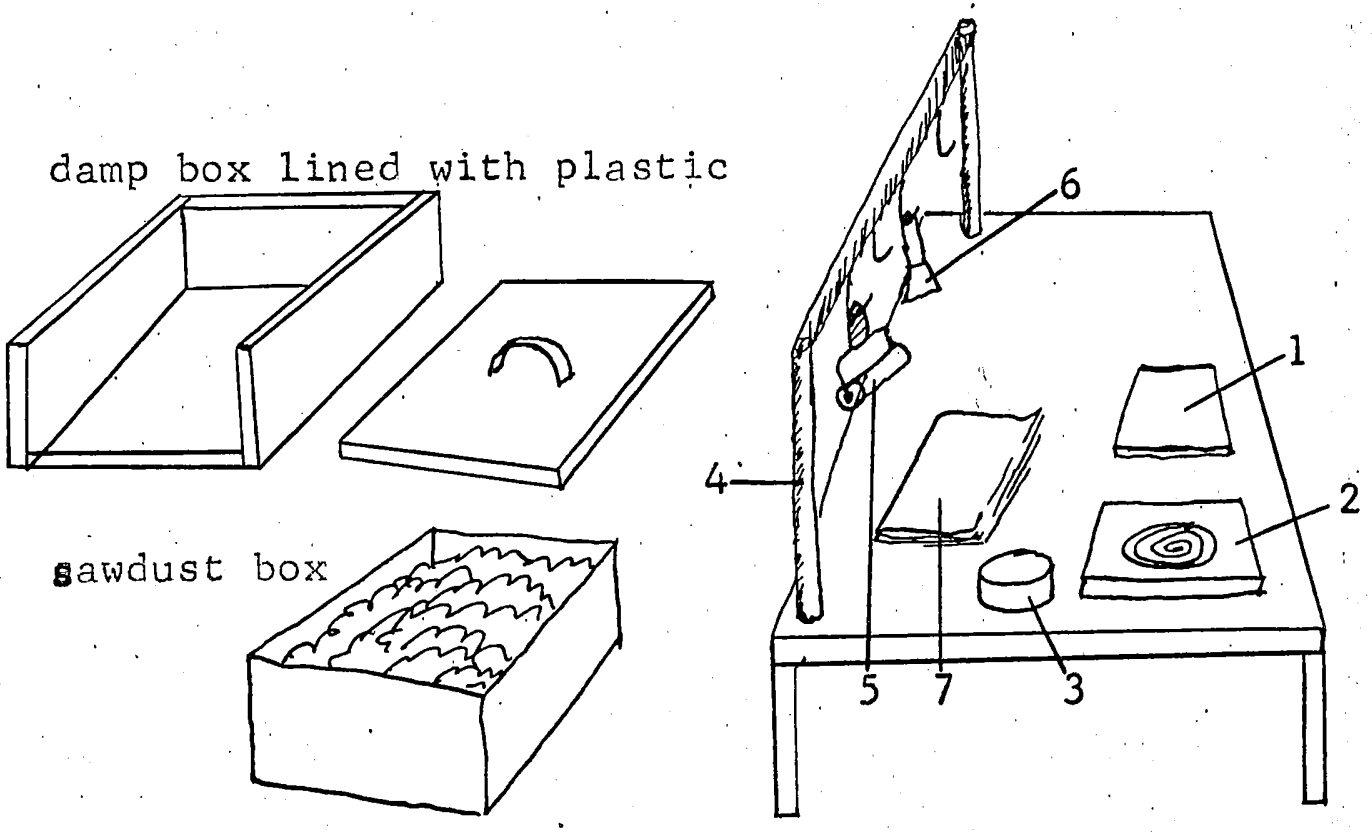
Supply company

Andrews, Nelson and whitehead 7 Laight street

New York. N. Y. 10013

Cal1fornia Ink Co. 501 15th Street

San Francisco, Callfornia.

Charles Brand Machinery Inc.

84 East 10th street

New York, N. Y. 10003

Continental Felt Company

22-26 West 15th streat

New York, N.Y. 10011

Copper and Brass Sales. Inc.

6555 E. Division

Detro1t 12. M1chigan

Craftools. Inc.

396 Broadway

NeW York, N.Y. 10003

Diamond Pointed Tool Co.

Atlantic Highlands

New Jersey

Edward D1okerson

2034 N. Mohawk Street

ChIcago. Illinols

Edward C. Muller

61-3 Frankfort street

New York 38, N.X.

Frank M1ttermeler, Ino.

3577 East Tremont Ave.

Bronx 65. N.Y.

Graphle Chemlcal and Ink Co.

P.0. Box No. 27

728 North Yale Avenue

Villa Park. Illinois

M. Grumbacher

460 East 34 th Street

New York, N.Y.
Product

paper

ink

presses

felt blankets

plates

press, tools

drypoint styluses

$\$ 5.00$ each

press

engraving tools general.

tools

general

general 
Langeneckert. Inc.

705 pine street

St. Louls, Missour1 63101

Leber Ink Co.

Box 606

Tukwila. Washington 9806 ?

Montana Assay offlce

610 S.W. 2nd Avenue

Portland, Oregon 97204

National Steel and Copper Co. 700 South cilnton Avenue

Chicago. Illinols

Mr. Joseph sternberg

Newark Dressmaker supply Co.

140 Hàl sey street

Newark 2, New Jersey

Harold M. PI tman Company

230 West $418 t$ Street

New York. N.X.

Rembrandt Graphic Arts Co.. Inc. general

Stockton, New Jersey 08559

F. Weber Company

1220 Buttonwood street

Philadelphla. Pennsylvania

Zellerbach Paper Co. 245 South spruce street South San Franc1sco, Calif. press pg. 190 general

1nk, esp. collagraph

tools, sheet metal, general

copper sheet

tarlatans

plates, ink

tools, grounds

paper 
III. The Organization of Materials in the classroom

storage is always a problem in the secondary school art class. Fortunately, the materials for intaglio printing. with the exception of the press, are small and 1ight welght. They can be easily stored on shelves or in drawers like other art supplies. The tarlatans and ink cans are the only dirty 1 tems after cleanup and should be kept in plastic sacks in a separate drawer. The tarlatans can be folded over wire clothes lines above the printing area.

The materlals used for working on the plate and those used in printing are kept in different areas. I prefer to do all of my work on the plate in a room separate from the printing room, but this is nelther economical nor convenlent for an entire class. Each table of four to six students should have a box with the varlous tools for working on the plate in the center of their table. In this way the tools are accessible to all students at the table and are easily checked at the end of each period. Sharp pointed tools. such as burins and drypoint needles, can be stuck into a plece of cork or into a one-inch thick board with holes drilled 3/4" through.

It 18 important that each group of students be held accountable for 1 ts tools and that the tools are kept clean and orderly for use in the next class. The students will respect this method of organization and find that it is conducive to their work and work habits. 
The printing area is by nature a alrty area and requires greater organization. In most cases a table model press is used. It is mounted on heavy wooden bench with drawers ox shelve below. When the press is not in use it should be covered with a plastio cloth, such as an old tablecloth. Ink, oleaning solvents, dauber, spatulas, and the plate of glass should be kept in the same area as the press. The best place would be in drawers beneath the press if they are provided.

The wiplng table servea several purposes and 1s located In the printing area. It should have a supply of old newspapers at one end that can be put under the plate whlle wiping. The table must be large enough to accommodate the plate of Glass, newspapers, hotplate, k1tchen rack, and an area to wipe the plate. Inking brayers and spatulas are hung on the rack during wiplng. 5

Items 11ke the sandpaper, sharpening stone, and printing paper are distributed by the teacher as the need arises for the1 use. At the beginning of each new project the students 111 also recelve their printing plates in a almilar manner. The 1dea of order and consistent placement of materials cannot be stressed too much. Efficient oleanup and work habits should be built into the organization of the clessroom.

5 see page 27 for detalls of the inking table and refer to Lumsden for total room layout. 
Four people should be assigned to take care of the materials that are used by the entire olass. The press is dusted and covered with a plastic tablectoth. The felt blankets are taken off the press and placed singly on a rack or hung on a clothesine to air dry. The press bed is centered and the pressure lever for the top roller is released. The cans of ink and the spatulas are wiped olean and put away. The inking brayers are cleaned by scraping the excess ink of with a plece of stiff rubber or cardboard and then rolling the brayers on a newspaper that is soaked wh therosene. The brayers are hung on the rack over the wiping table. The blotters in the dampening box should be neat and flat. The lnking slab, whioh is in this case a plate of glass. is wiped clean with kerosene and rag. The hand cleaners and creams are put in a drawer. Finaliy, the sinks must be cleaned.

This should take four high school students less than ten minutes to complete. A mimeographed cleanup sheet with the dutles for four people can be posted each Monday morning for quick reference during the week. 
The steps of the printing procedure in chronological order are as follows:

1. Wet several papers and place between blotters

2. Extend the bed of the press to one end

3. Arrange the blankets in order as shown on page 34

4. Place a clean sheet of newsprint on the bed of the press just in front of the roller

5. Ink and wipe the plate (warm metal plates before 1nking)

6. Place the plate on the bed (newsprint under the plate)

7. Center the blotted paper on the plate

8. Smooth blankets over the plate

9. Turn handle of press until the bed completely travels through the press

10. 1ift the print by one corner and pull from plate

11. Stretch the print with paper tape 


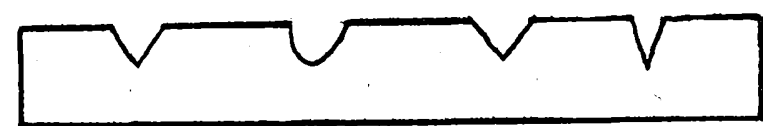

engraved line after scraping
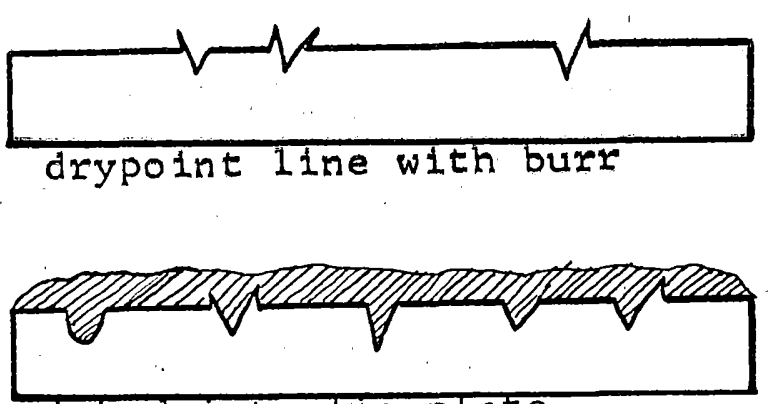

inked intaglio plate

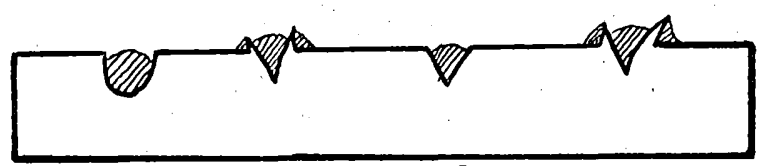

wiped intaglio plate

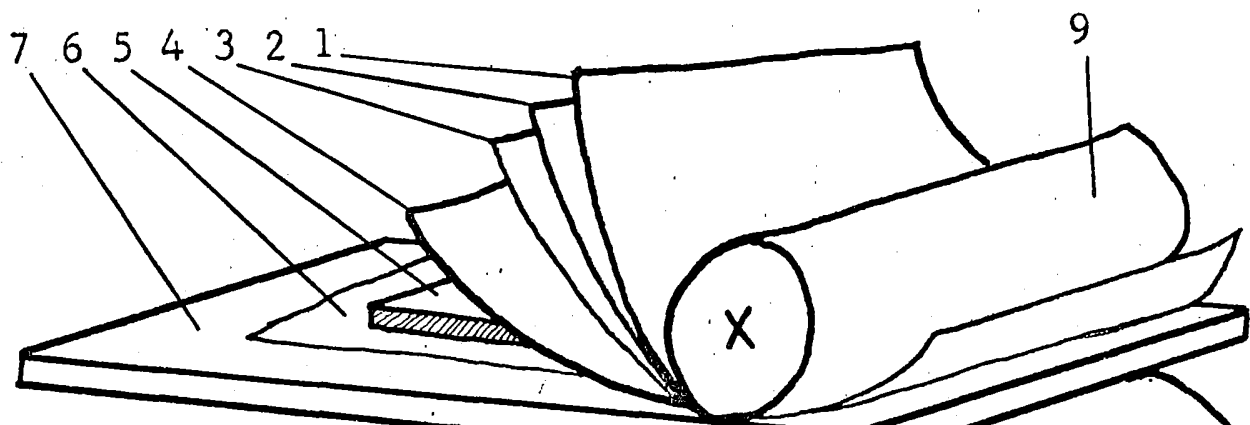

1. pusher blanket

2. cushion blanket

3. sizing catcher

4. etching paper

5. printing plate

6. clean newsprint

7. bed of press

8. bottom roller

9. top roller

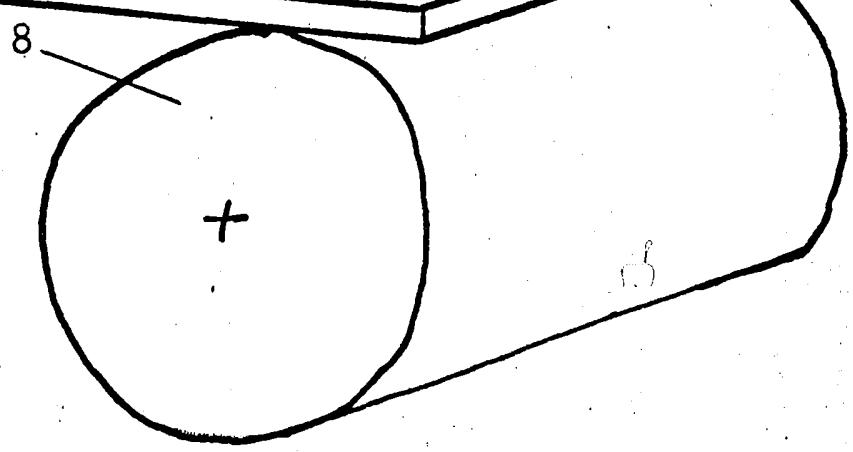


PHOTOGRAPHS OF THESIS PRINTS 


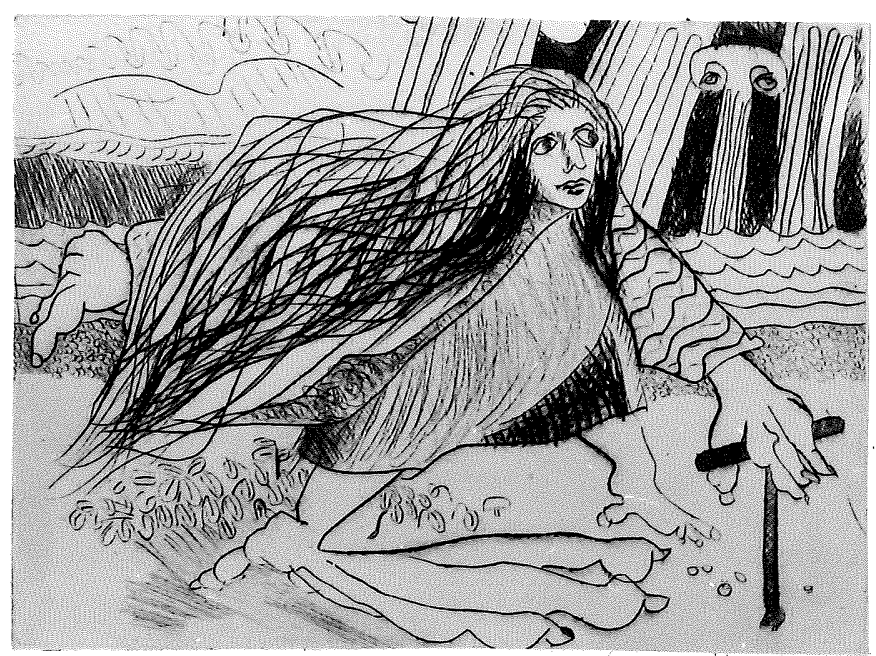

1. MLte: Vorlaly Mother"

Plate: copper

Tools: arypolnt

Size $6 \times 81 n$.

2.

Title: untstled

Plate: x-ray Plim

Tools: sandpaper drypolnt Size 8 z 10 in.

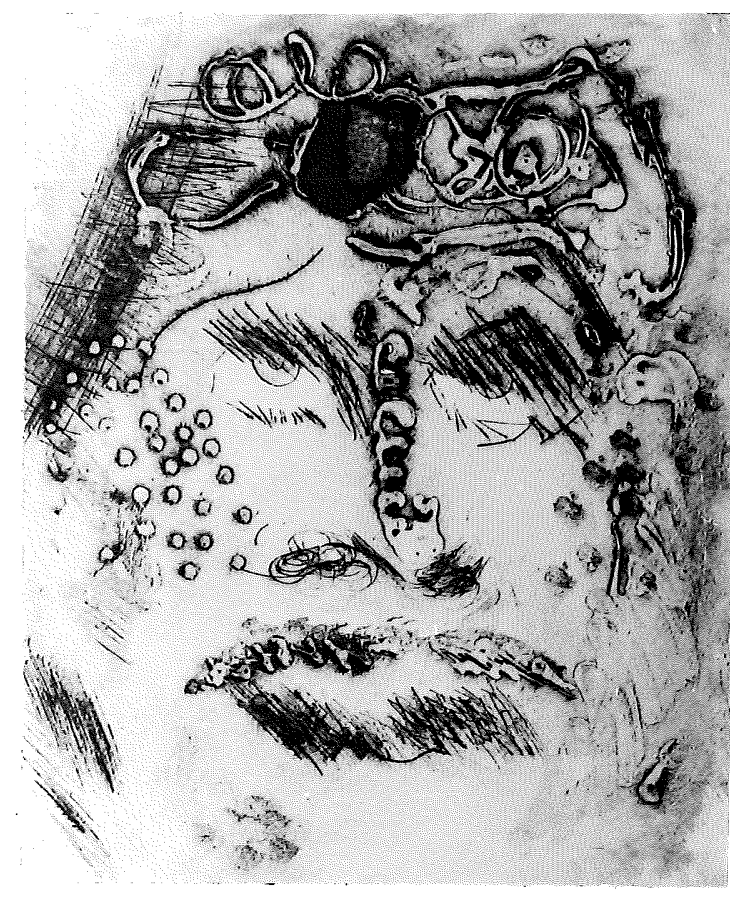




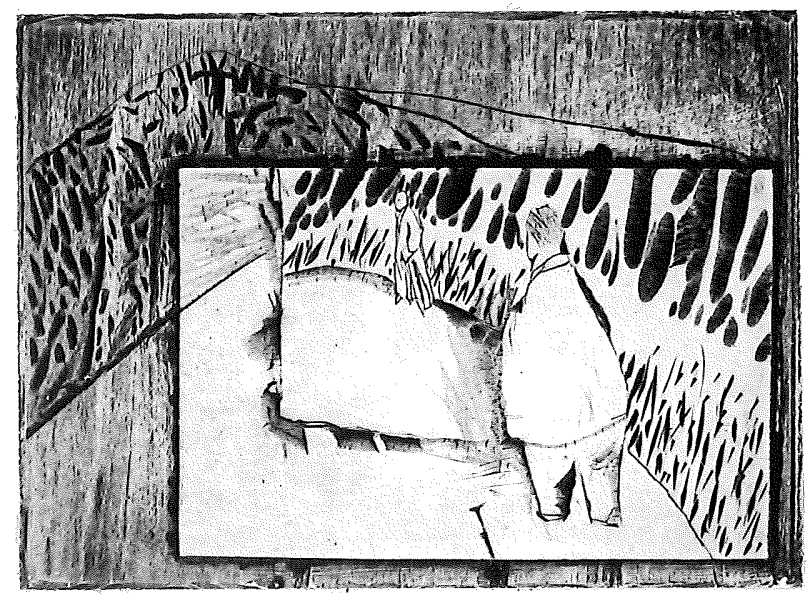

3. TLtze: "Gloomy Sundey"

Plate: plywood with inoleum

Tools: woodcut gouges

size: $53 / 4 \times 73 / 41 n$.

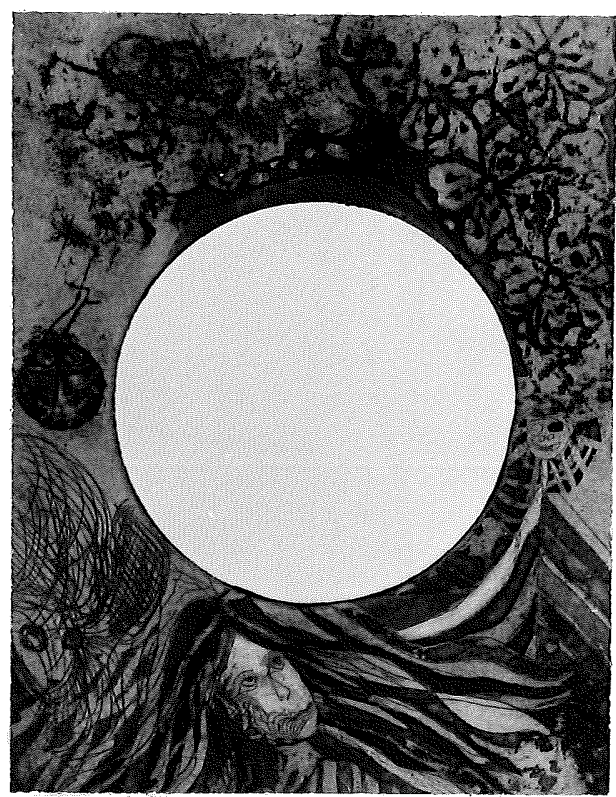

4.

Title: "The Oblong Blur" Plate: copper

Tools: etohing, arypoint Size: $51 / 2 \times 7$ in.

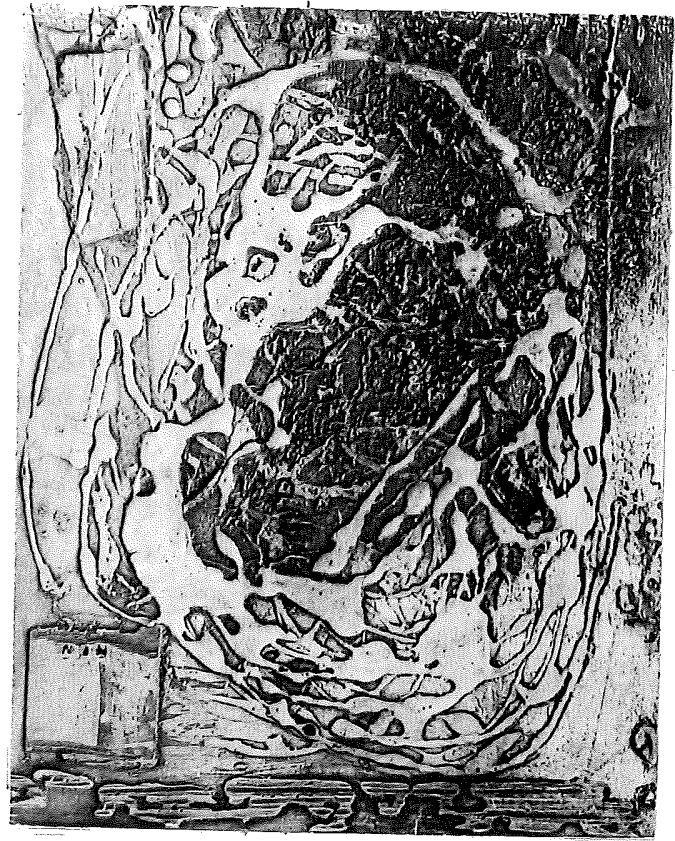

5

Title: "Travail"

Plate: masonite

Tools: glue, pencil shavings size: $71 / 2 \times 91 / 21 n$. 


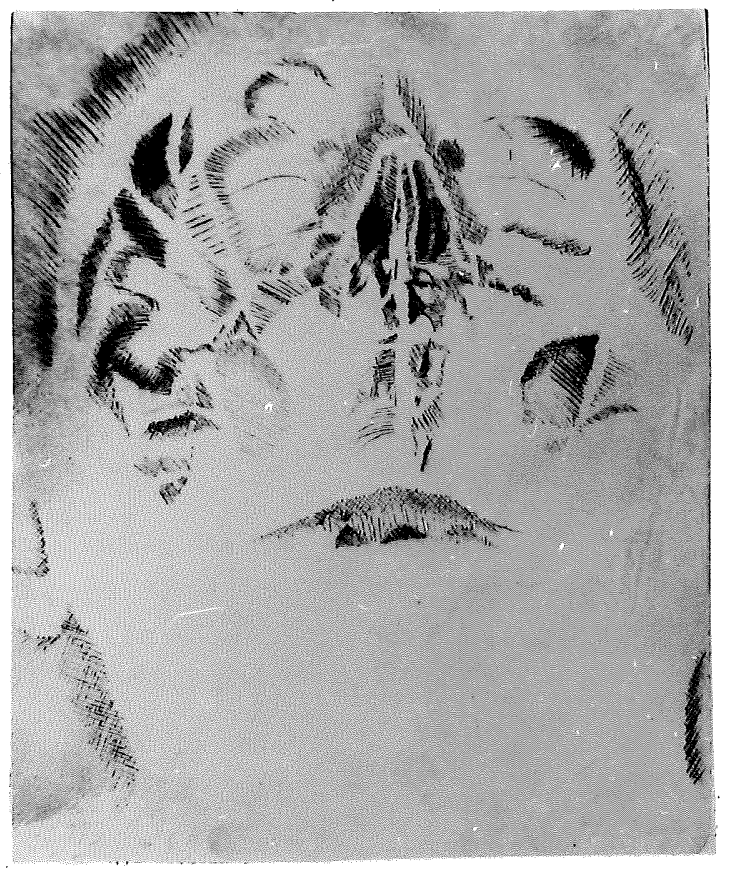

6.

T1 tle: "Head"

Plate: x-ray $211 \mathrm{~m}$

Tools: arypolnt with pin Size : 8 × 10 in.

7.

T1t2e: "The Allens" Plate: zinc

Tools etching

size: $43 / 4 \times 7$ in.

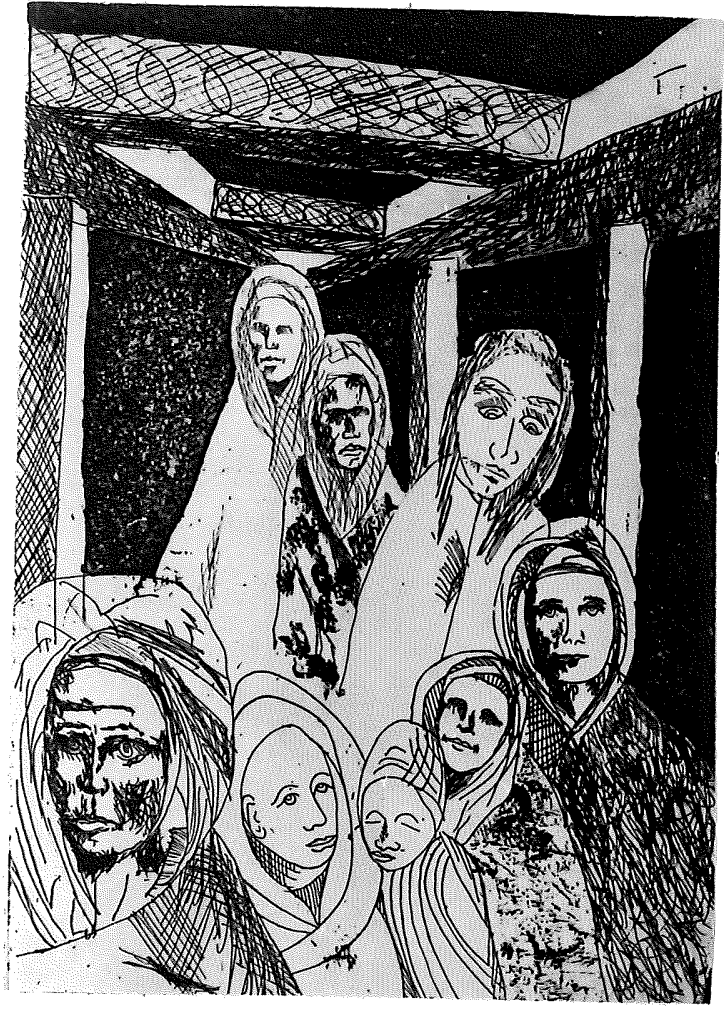


PRINTS BY STUDENTS FROM CLEVELAND HIGH SCHOOL 


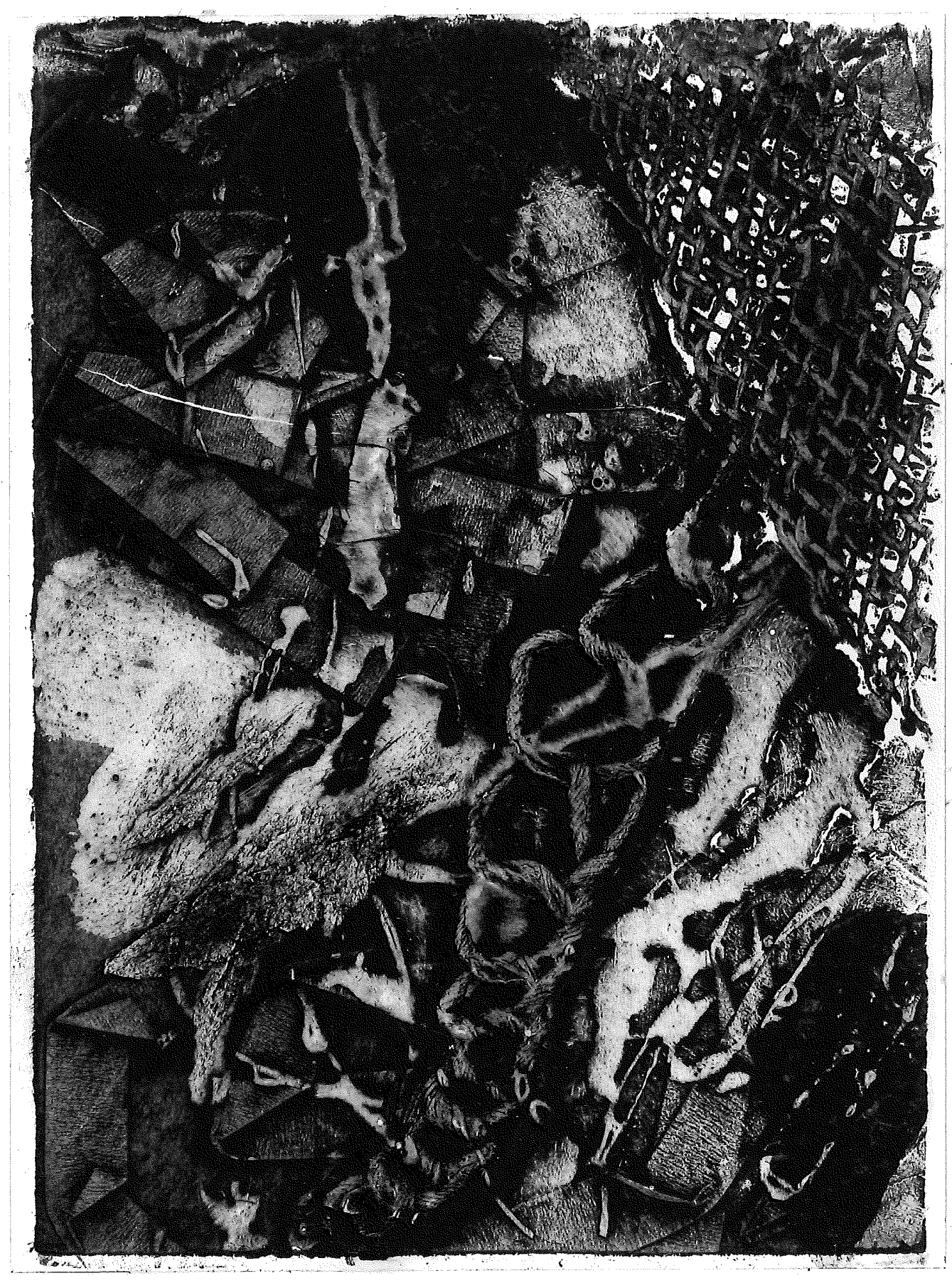

1. Collagraph print 


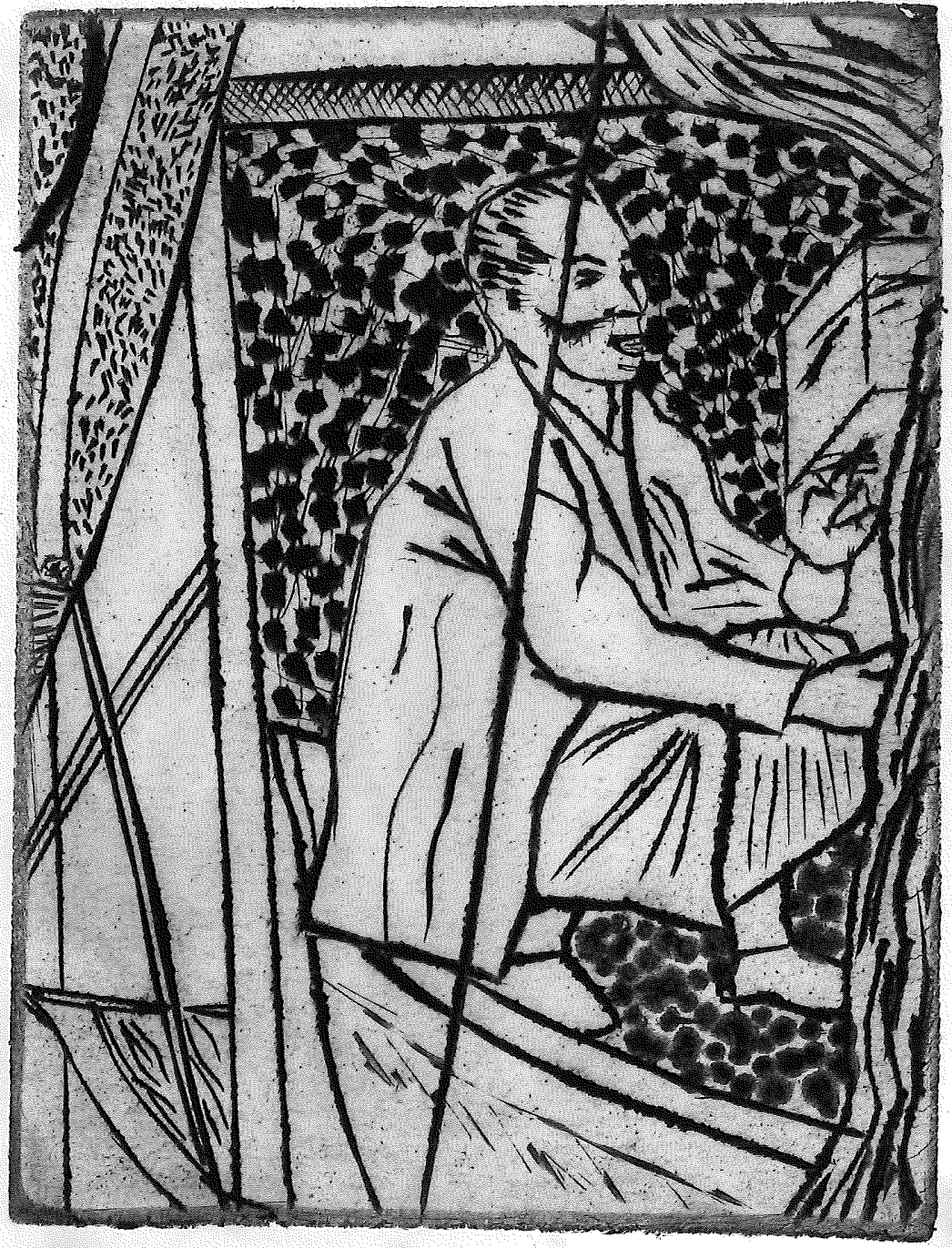

2. Isnoleum print 


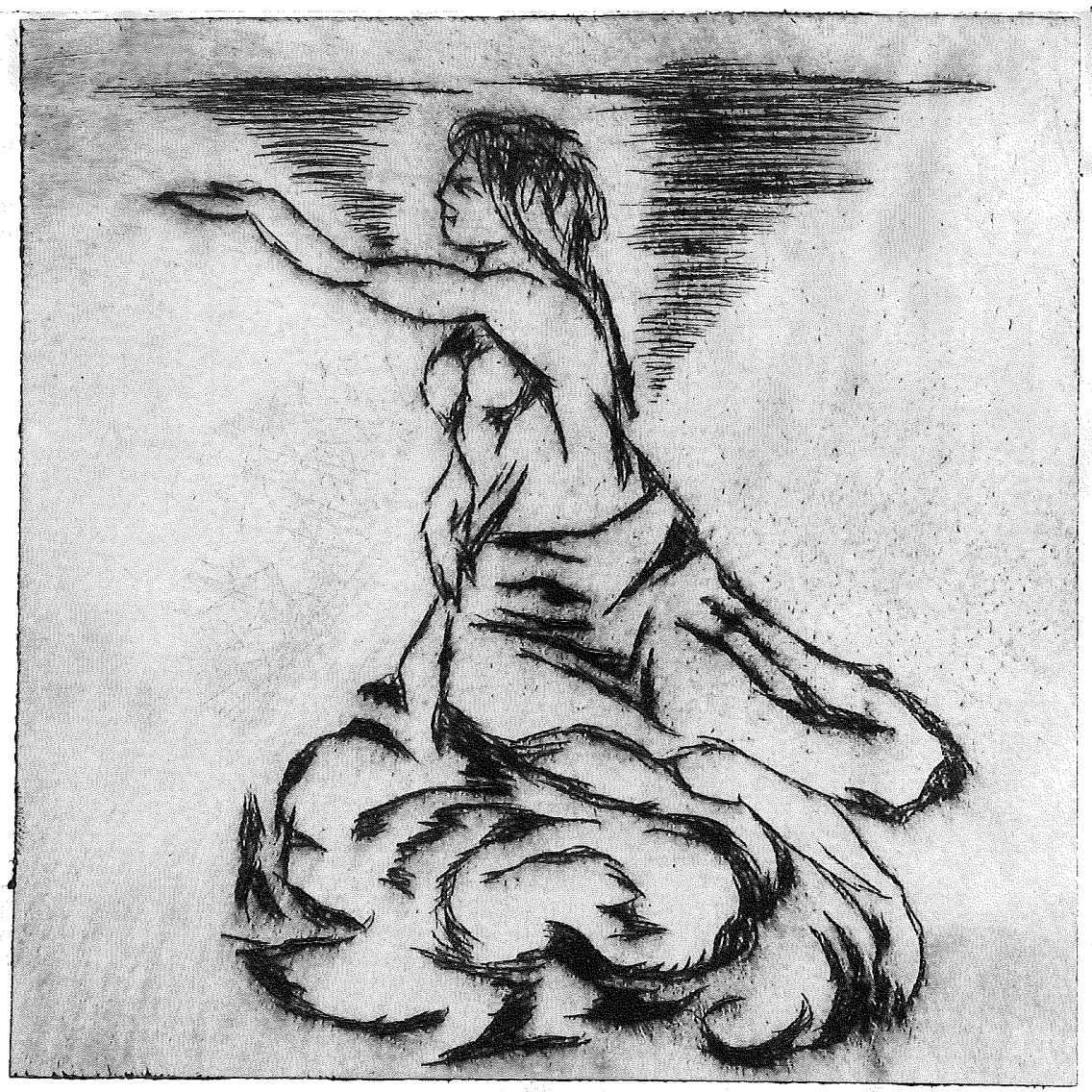

3. $x-r a y$ sim print 


\section{A selected Bibllography}

Erunner, Fel1x, A Handbook of Graphle Eeproduction. New York. 1962.

Heller, Jules, Erintmaklng Today. New York, 1958.

Hayter, Stanley 1211 an. About Prints. London, 1962.

Hayter, stanley W1111am, Now Ways of Gravure. Now Xork, 1949.

Ivins, William. JP., How prints Look. Boston. 1945.

Ivins, Willian M. Jr.. Prints and V1sual Communloation. Cambridge, 1953.

Hind, Arthur M. A History of gtohing and Engraving. New York, 1963.

Lalanne. Maxime, Treatise on gtohing. Boston. 1885.

Lumsden. Ernest S.. The Art of Etohing. London, 1925.

Now York Museum of Modern Art, Odilon Bedon, Gustave Moreau, Rodolphe Breaden. New York. 1961.

Peterd1. Gabor. Printmaking. Now York. 1959.

Roger-Marx, Claude, Graphlo Art of the 19th Century. New York. 1962.

Strang, David. The Printing of Etohings and Engravings. London, 1930.

Untracht, Opp1, Metal Techniques for Craftsmen.

New York. 1968. 
APPENDIX 

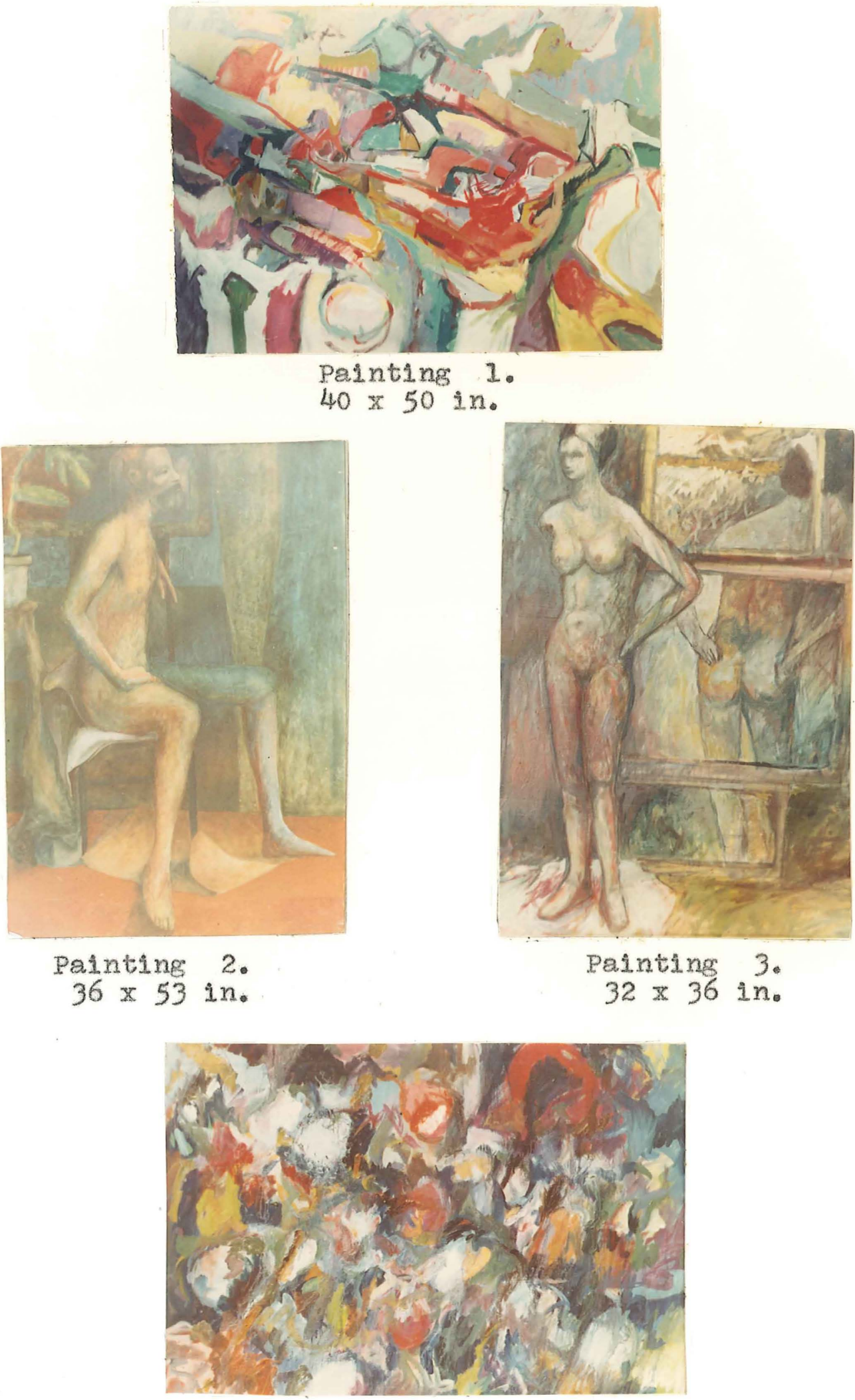

Painting 4. 


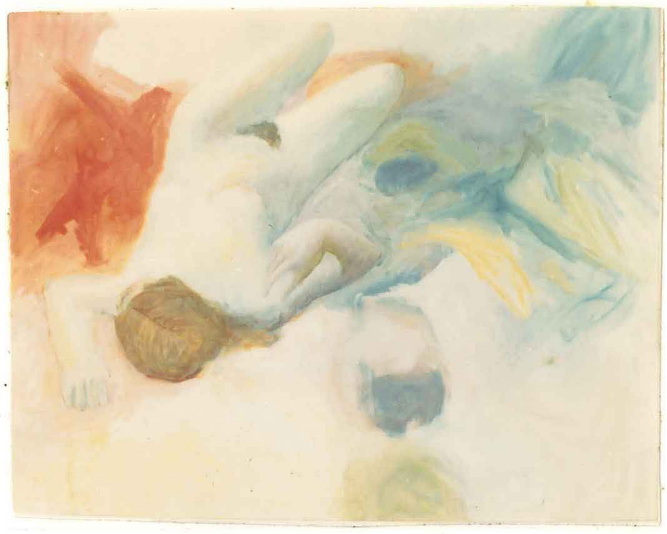

Painting 5 .

$41 \times 57$ in.
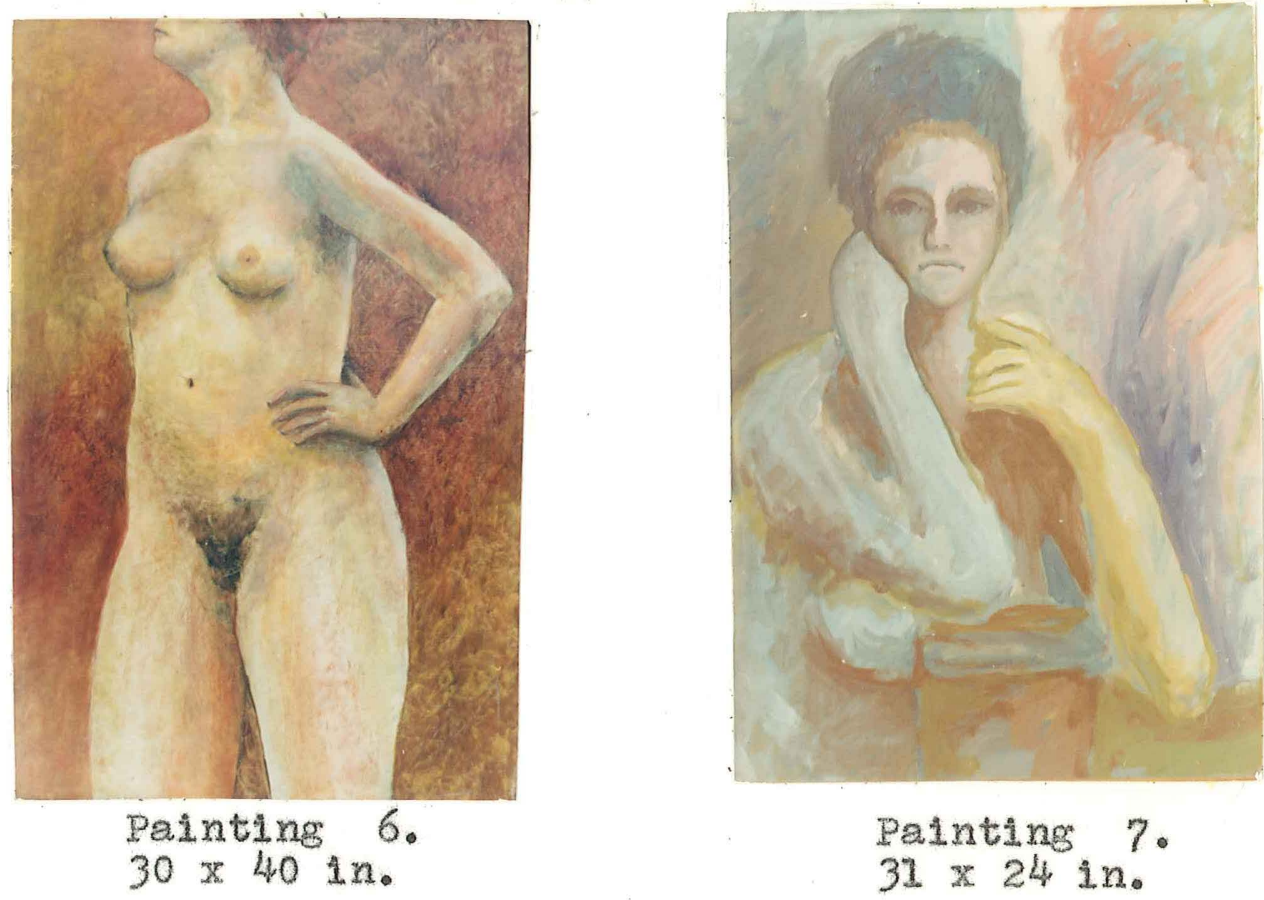

$\frac{\text { Painting }}{30 \times 40}$ in.

Painting 7 .

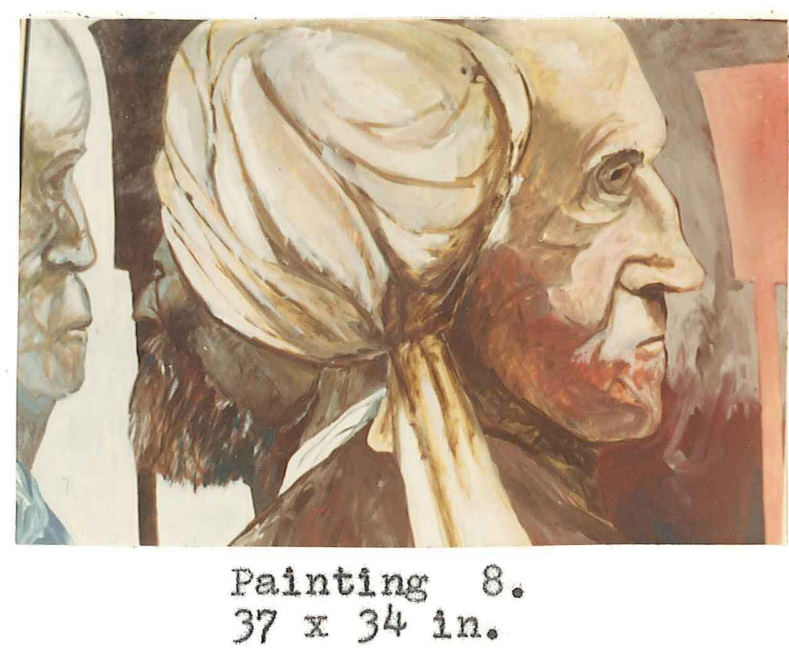



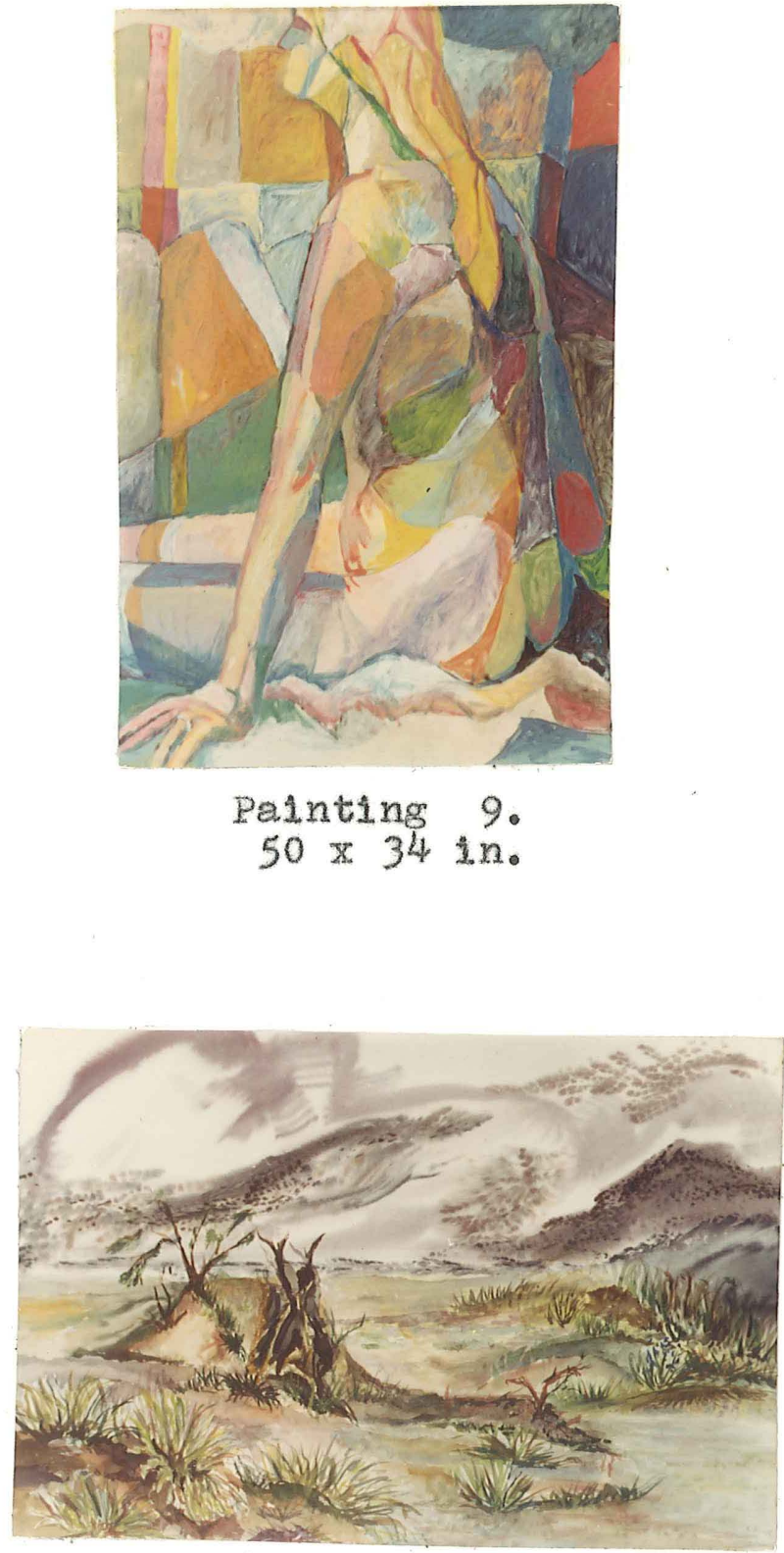

Painting 10 . watercolor $20 \times 30$ in. 

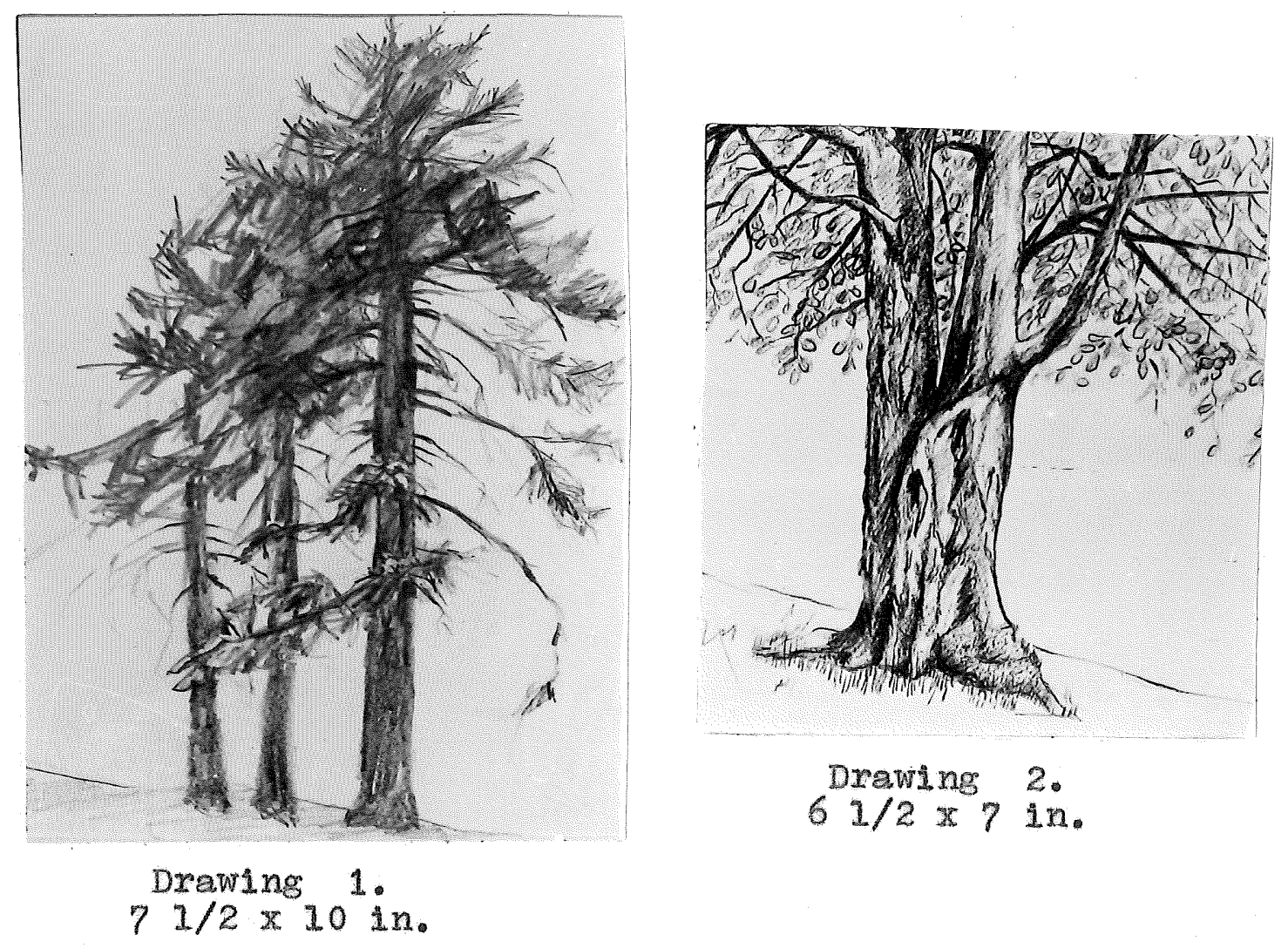

$71 / 2 \times 10^{1} \mathrm{in}$

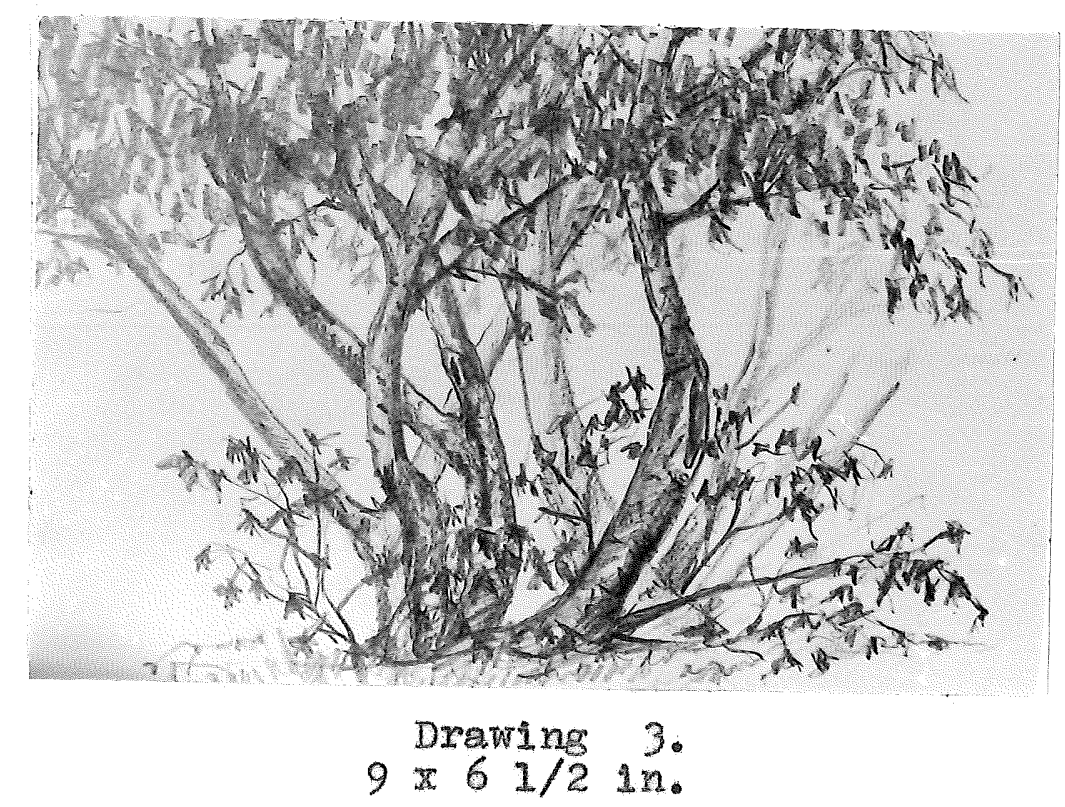

